\title{
A methodology for estimating concentrations of pharmaceuticals and personal care products (PPCPs) in wastewater treatment plants and in freshwaters
}

DOI:

10.1016/j.scitotenv.2017.12.059

\section{Document Version}

Accepted author manuscript

Link to publication record in Manchester Research Explorer

Citation for published version (APA):

Tarpani, R. R. Z., \& Azapagic, A. (2018). A methodology for estimating concentrations of pharmaceuticals and personal care products (PPCPs) in wastewater treatment plants and in freshwaters. Science of the Total Environment, 622-623, 1417-1430. https://doi.org/10.1016/j.scitotenv.2017.12.059

Published in:

Science of the Total Environment

\section{Citing this paper}

Please note that where the full-text provided on Manchester Research Explorer is the Author Accepted Manuscript or Proof version this may differ from the final Published version. If citing, it is advised that you check and use the publisher's definitive version.

\section{General rights}

Copyright and moral rights for the publications made accessible in the Research Explorer are retained by the authors and/or other copyright owners and it is a condition of accessing publications that users recognise and abide by the legal requirements associated with these rights.

\section{Takedown policy}

If you believe that this document breaches copyright please refer to the University of Manchester's Takedown Procedures [http://man.ac.uk/04Y6Bo] or contact uml.scholarlycommunications@manchester.ac.uk providing relevant details, so we can investigate your claim.

\section{OPEN ACCESS}




\title{
A methodology for estimating concentrations of pharmaceuticals and personal care products (PPCPs) in wastewater treatment plants and in freshwaters
}

\author{
Raphael Ricardo Zepon Tarpani and Adisa Azapagic*
}

School of Chemical Engineering and Analytical Science, The University of Manchester, Room C16, The Mill, Sackville Street, Manchester M13 9PL, UK

*Corresponding author: adisa.azapagic@manchester.ac.uk.

\begin{abstract}
Despite an increasing number of studies on pharmaceuticals and personal care products (PPCPs), data on their concentrations in the environment are still scant. This is due to many factors, including great variability in usage and physicochemical properties of these compounds, which contribute to their widespread presence and complex behaviour, particularly in the aquatic environment. The main pathway for their discharge into the waterways is through wastewater treatment plants (WWTPs), which are inefficient in removing many of PPCP compounds. Therefore, aiming to contribute to a better understanding of the role that WWTPs play in the presence of PPCPs in the environment, this paper proposes a new method for estimating the expected concentrations of these compounds in WWTP influents, effluents and sludge, as well as their expected discharge and related concentrations in freshwaters. The proposed method can assist with future eco-toxicological and environmental risk assessments as well as the development of policies and regulation related to PPCP compounds.
\end{abstract}

Keywords: freshwater pollution; pharmaceutical and personal care products; predicted environmental concentration; sewage sludge; wastewater treatment.

\section{Introduction}

The environmental presence of compounds from pharmaceuticals and personal care products (PPCPs) has been increasing over the years as a result of the growing consumption of PPCPs associated with the aging population, advances in disease treatments and expansion of health care systems (Hill \& Chu 2009, Liu \& Wong 2013). One of the main routes for PPCPs to reach the environment is wastewater treatment plants (WWTPs) which are ineffective in removing these chemicals, unless advanced treatment methods are used (Michael et al. 2013, Ratola et al. 2012, Verlicchi \& Zambello 2015). As a result, effluents discharged into the waterways can contain significant amounts of these compounds and can eventually reach potable water, particularly through freshwaters and groundwater. In some cases, PPCPs are present in potable water at concentrations found in the environment, indicating that conventional drinking water treatment plants are also ineffective in removing them (Carmona et al. 2014, Luo et al. 2014). As a consequence, concerns have been raised about the fate of PPCPs in the environment and their potential health effects over a long-term exposure through drinking water. This is particularly important given a great diversity of these compounds and the synergism among their metabolites, interactions with other compounds or their degradation products (Benotti et al. 2009, Kumar \& Xagoraraki 2010). Recognising the importance of PPCPs in the environment, the European Directive 2013/39/EU defined a watch list for EU-wide monitoring for the following eight compounds: 2-Ethylhexyl 4-methoxycinnamate, 17-Alpha-ethinylestradiol (EE2), 17-Beta-estradiol (E2), Azithromycin, Clarithromycin, Diclofenac, Erythromycin, and Estrone (E1) (European Commission 2015).

However, data on the discharge of PPCPs from WWTPs and on their concentrations in the environment exhibit great variability, leading to inconclusive results (Blair et al. 2015, Boxall et al. 2014, Luo et al. 2014, Verlicchi \& Zambello 2015, Verlicchi et al. 2012). This is not surprising, 
given the large number of variables involved, including consumption of PPCPs, their influent concentration in WWTPs, sewage composition and plant operating parameters. As a result, there are many data gaps (Petrie et al. 2015) warranting further studies on the contribution that wastewater treatment has on the presence of PPCPs in the environment.

While the effects of these chemicals on the environment and human health are still subject of ongoing research, it is generally accepted that they could cause detrimental effects on wildlife owing to their eco-toxicological properties, even without considering the metabolites and synergetic effects (Cleuvers 2003, Fent et al. 2006, Martín et al. 2012, Verlicchi et al. 2012, Yazdankhah et al. 2006). Although the creation of metabolites is high for many compounds, a significant number of PPCP compounds are environmentally persistent and difficult to remove once in the environment (Farré et al. 2008, Kagle et al. 2009, Loffler et al. 2005, Xu et al. 2009).

Currently, predictions on the presence of PPCPs in WWTPs and freshwaters are largely based on prescription or sales data and disregard dilution and other operating parameters in WWTP plants. This approach is unreliable due to many factors, including incomplete sales data, fluctuations in consumption patterns and differing conditions in WWPT plants (Celle-Jeanton et al. 2014, Oosterhuis et al. 2013, Verlicchi et al. 2014). Therefore, the following aspects require further attention (Shannon et al. 2008; Siemens et al. 2008; Bolong et al. 2009; Christensen et al. 2009; Miège et al. 2009; Walters et al. 2010; Gottschall et al. 2012):

- determining concentrations of PPCPs in WWTP influents;

- determining concentrations in the effluent after the secondary treatment in WWTPs at which advanced treatment methods should be used to reduce the impact on the environment or to enable wastewater reuse;

- identifying safe levels of discharge of these substances from WWTPs; and

- determining the necessity for monitoring the effluents and sludge for the presence of certain PPCP compounds.

In an attempt to address some of these research challenges and inform policy, this work proposes a new methodology for estimating expected concentrations of PPCPs in WWTP influents, effluents and sludge, based on data from direct measurements available in literature. These estimates are then used to predict concentrations of target compounds in freshwaters. The proposed method can assist future eco-toxicological and environmental risk assessments as well as development of policies and regulation related to PPCP compounds.

\section{Methodology}

The proposed methodology involves the following four steps:

1. selection of target PPCPs and data collection;

2. estimation of the influx of PPCPs into WWTPs and their removal efficiencies;

3. estimation of concentration ranges of PPCPs in WWTPs; and

4. estimation of expected concentrations of PPCPs in freshwaters.

These steps are described in the next sections.

\subsection{Selection of target PPCP compounds and data collection}

The first step of the methodology involves selection of target PPCPs from over 3,000 compounds currently used in Europe alone (Daughton \& Ternes 1999; Roig 2010; World Health Organization 2004). In this work, the target compounds have been selected based on data availability, environmental risks they pose, their different physicochemical properties (and hence different behaviour during wastewater treatment) and inclusion in the European watch list. As a result, the following 14 PPCP substances ubiquitous in WWTPs are considered (Radjenović et al. 2009; Jelic et al. 2011; Petrie et al. 2015): 
Accepted for publication in Science of the Total Environment 622-623 (2018) 1417-1430

- analgesics: acetaminophen, diclofenac and ibuprofen;

- antibiotics: erythromycin, trimethoprim and sulfamethoxazole;

- beta blockers: metoprolol;

- lipid regulators: gemfibrozil and bezafibrate;

- psychiatric drugs: carbamazepine;

- hormones: estrone and $17 \beta$-estradiol;

- antiseptics: triclosan; and

- stimulants: caffeine.

To enable estimation of the parameters in steps 2-4 of the methodology, the following data need to be collected based on the actual WWTPs and measurements:

- influent and effluent concentrations of the target PPCPs;

- wastewater influent into WWTPs; and

- population served by WWTPs.

As part of this research, the above data were collected from the literature for 81 full-scale WWTPs in different countries, spanning a range of operating parameters and treatment types. These data are summarised in Table 1, sorted by the region, starting with the countries in North America and followed by those in Asia, Europe and, finally, Australia.

Table 1 Target PPCPs in wastewater treatment plants in different countries

\begin{tabular}{|c|c|c|c|c|}
\hline $\begin{array}{l}\text { Location of WWTP } \\
\text { (Source of data) }\end{array}$ & $\begin{array}{l}\text { Compounds and their average } \\
\text { concentrations in WWTP (influent; } \\
\text { effluent) }(\mu \mathrm{g} / \mathrm{L})\end{array}$ & $\begin{array}{l}\text { Influent water } \\
\text { flow }\left(\mathrm{m}^{3} / \mathrm{d}\right)\end{array}$ & $\begin{array}{l}\text { Population served } \\
\text { (no. of inhabitants) }\end{array}$ & $\begin{array}{l}\text { Treatment } \\
\text { type }\end{array}$ \\
\hline US (Gao et al. 2012) & $\begin{array}{l}\text { Sulfamethoxazole }(1.10 ; 0.10) \\
\text { Carbamazepine }(0.10 ; 0.20) \\
\text { Caffeine }(42.0 ; 0.70)\end{array}$ & 45,400 & Not stated & Activated sludge \\
\hline US (Conkle et al. 2008) & $\begin{array}{l}\text { Acetaminophen }(39.3 ; 0.02) \\
\text { Ibuprofen }(9.92 ; 0.08) \\
\text { Sulfamethoxazole }(4.09 ; 0.31) \\
\text { Metoprolol }(0.21 ; 0.02) \\
\text { Gemfibrozil }(1.65 ; 1.82) \\
\text { Carbamazepine }(0.06 ; 0.09) \\
\text { Caffeine }(25.6 ; 0.03)\end{array}$ & 7,200 & Not stated & $\begin{array}{l}\text { Constructed } \\
\text { wetland }\end{array}$ \\
\hline $\begin{array}{l}\text { US (Thomas \& Foster } \\
\text { 2005) }\end{array}$ & $\begin{array}{l}\text { Diclofenac }(0.47 ; \sim 0.0) \\
\text { Ibuprofen }(9.50 ; 0.02) \\
\text { Triclosan }(3.00 ; 0.08) \\
\text { Caffeine }(43.8 ; 0.04)\end{array}$ & 11,300 & 194,000 & Activated sludge \\
\hline US (Batt et al. 2007) & $\begin{array}{l}\text { Trimethoprim }(7.90 ; 0.26) \\
\text { Sulfamethoxazole }(2.80 ; 0.63)\end{array}$ & 113,562 & Not stated & $\begin{array}{l}\text { Activated sludge } \\
+ \text { sand filter }\end{array}$ \\
\hline US (Yang et al. 2011) & $\begin{array}{l}\text { Acetaminophen }(80.0 ; 0.05) \\
\text { Diclofenac }(0.22 ; 0.01) \\
\text { Ibuprofen }(11.0 ; 0.06) \\
\text { Trimethoprim }(0.61 ; 0.28) \\
\text { Erythromycin }(0.34 ; 0.27) \\
\text { Sulfamethoxazole }(2.60 ; 0.42) \\
\text { Carbamazepine }(0.23 ; 0.25) \\
\text { Triclosan }(0.47 ; 0.02) \\
\text { Caffeine }(80.0 ; 0.07)\end{array}$ & 227,000 & Not stated & $\begin{array}{l}\text { Membrane } \\
\text { bioreactor }\end{array}$ \\
\hline $\begin{array}{l}\text { Canada (Lishman et al. } \\
\text { 2006) }\end{array}$ & $\begin{array}{l}\text { Diclofenac }(0.20 ; 0.19) \\
\text { Ibuprofen }(8.45 ; 0.38) \\
\text { Gemfibrozil }(0.45 ; 0.25) \\
\text { Estrone }(0.03 ; 0.01) \\
\text { Triclosan }(1.93 ; 0.11)\end{array}$ & 202,133 & Not stated & Several $^{\mathrm{a}}$ \\
\hline $\begin{array}{l}\text { Canada (Atkinson et al. } \\
\text { 2012) }\end{array}$ & $\begin{array}{l}\text { Estrone }(0.05 ; 0.10) \\
17 \beta \text {-estradiol }(0.05 ; 0.003)\end{array}$ & 422,000 & 786,130 & Activated sludge \\
\hline $\begin{array}{l}\text { South Korea (Behera et } \\
\text { al. 2011) }\end{array}$ & $\begin{array}{l}\text { Acetaminophen }(7.50 ; 0.01) \\
\text { Diclofenac }(0.15 ; 0.02) \\
\text { Ibuprofen }(2.20 ; 0.15) \\
\text { Trimethoprim }(0.20 ; 0.04) \\
\text { Sulfamethoxazole }(0.09 ; 0.09)\end{array}$ & 451,000 & $1,100,000$ & Several $^{b}$ \\
\hline
\end{tabular}




\begin{tabular}{|c|c|c|c|c|}
\hline & $\begin{array}{l}\text { Metoprolol }(0.005 ; 0.004) \\
\text { Gemfibrozil }(0.20 ; 0.02) \\
\text { Carbamazepine }(0.10 ; 0.08) \\
\text { Estrone }(0.05 ; 0.02) \\
17 \beta \text {-estradiol }(0.004 ; \sim 0.00) \\
\text { Triclosan }(0.55 ; 0.10) \\
\text { Caffeine }(2.50 ; 0.02)\end{array}$ & & & \\
\hline $\begin{array}{l}\text { South Korea (Sim et al. } \\
\text { 2010) }\end{array}$ & $\begin{array}{l}\text { Acetaminophen }(8.00 ; \sim 0.00) \\
\text { Diclofenac }(0.01 ; 0.01) \\
\text { Ibuprofen }(1.00 ; \sim 0.00) \\
\text { Erythromycin }(0.75 ; 0.15) \\
\text { Gemfibrozil }(0.02 ; \sim 0.00) \\
\text { Carbamazepine }(0.30 ; 0.20) \\
\text { Caffeine }(6.00 ; 0.02) \\
\end{array}$ & $1,302,100$ & $3,600,000$ & Several $^{\mathrm{c}}$ \\
\hline $\begin{array}{l}\text { South Korea (Choi et al. } \\
\text { 2008) }\end{array}$ & $\begin{array}{l}\text { Acetaminophen }(31.9 ; 0.01) \\
\text { Trimethoprim }(0.22 ; 0.05) \\
\text { Sulfamethoxazole }(0.52 ; 0.16) \\
\text { Carbamazepine }(0.23 ; 0.09) \\
\text { Caffeine }(27.4 ; 0.32)\end{array}$ & $1,710,000$ & Not stated & Activated sludge \\
\hline $\begin{array}{l}\text { Japan (Nakada et al. } \\
\text { 2006) }\end{array}$ & $\begin{array}{l}\text { Ibuprofen }(0.80 ; 0.01) \\
\text { Carbamazepine }(0.08 ; 0.05) \\
\text { Estrone }(0.04 ; 0.05) \\
17 \beta \text {-estradiol }(0.02 ; 0.01) \\
\text { Triclosan }(0.60 ; 0.10)\end{array}$ & $2,785,000$ & $4,688,000$ & Several $^{\mathrm{d}}$ \\
\hline $\begin{array}{l}\text { Japan (Nakada et al. } \\
\text { 2007) }\end{array}$ & $\begin{array}{l}\text { Ibuprofen }(0.40 ; 0.01) \\
\text { Carbamazepine }(0.08 ; 0.03) \\
\text { Estrone }(0.04 ; 0.02) \\
17 \beta \text {-estradiol }(0.02 ; 002) \\
\text { Triclosan }(0.55 ; 0.12) \\
\end{array}$ & 170,000 & 460,000 & $\begin{array}{l}\text { Activated sludge } \\
+ \text { sand filter }\end{array}$ \\
\hline $\begin{array}{l}\text { Japan (Hashimoto et al. } \\
\text { 2007) }\end{array}$ & $\begin{array}{l}\text { Estrone }(0.03 ; 0.04) \\
17 \beta \text {-estradiol }(0.012 ; 0.002)\end{array}$ & 158,012 & Not stated & Several $^{\mathrm{e}}$ \\
\hline $\begin{array}{l}\text { Hong Kong (Leung et } \\
\text { al. 2012) }\end{array}$ & $\begin{array}{l}\text { Trimethoprim }(0.20 ; 0.19) \\
\text { Erythromycin }(1.00 ; 1.00) \\
\text { Sulfamethoxazole }(0.10 ; 0.07)\end{array}$ & $2,081,000$ & $5,381,900$ & Several $^{f}$ \\
\hline $\begin{array}{l}\text { Hong Kong (Xu et al. } \\
\text { 2007) }\end{array}$ & $\begin{array}{l}\text { Erythromycin }(0.86 ; 0.74) \\
\text { Sulfamethoxazole }(0.05 ; 0.03)\end{array}$ & $1,725,000$ & $3,500,000$ & $\begin{array}{l}\text { Modified } \\
\text { activated sludge }\end{array}$ \\
\hline $\begin{array}{l}\text { Hong Kong (Gulkowska } \\
\text { et al. 2008) }\end{array}$ & $\begin{array}{l}\text { Trimethoprim }(0.21 ; 0.23) \\
\text { Erythromycin }(0.55 ; 0.51)\end{array}$ & $1,377,000$ & $3,500,000$ & $\begin{array}{l}\text { Modified } \\
\text { activated sludge }\end{array}$ \\
\hline China (Zhou et al. 2012) & $\begin{array}{l}\text { Estrone }(0.08 ; 0.012) \\
17 \beta \text {-estradiol }(0.04 ; 0.002)\end{array}$ & $1,000,000$ & $2,400,000$ & Activated sludge \\
\hline China (Sui et al. 2010) & $\begin{array}{l}\text { Diclofenac }(0.35 ; 0.20) \\
\text { Trimethoprim }(0.30 ; 0.10) \\
\text { Metoprolol }(0.10 ; 0.09) \\
\text { Gemfibrozil }(0.04 ; 0.03) \\
\text { Bezafibrate }(0.04 ; 0.01) \\
\text { Carbamazepine }(0.15 ; 0.12) \\
\text { Caffeine }(6.00 ; 0.01)\end{array}$ & $2,200,000$ & $6,109,000$ & Several $^{\mathrm{h}}$ \\
\hline $\begin{array}{l}\text { Spain (Gracia-Lor et al. } \\
\text { 2012) }\end{array}$ & $\begin{array}{l}\text { Acetaminophen }(55.1 ; \sim 0.00) \\
\text { Diclofenac }(0.53 ; 0.34) \\
\text { Ibuprofen }(14.6 ; \sim 0.00) \\
\text { Trimethoprim }(0.10 ; 0.09) \\
\text { Sulfamethoxazole }(0.45 ; 0.05) \\
\text { Gemfibrozil }(0.21 ; 0.49) \\
\text { Bezafibrate }(0.08 ; 0.06) \\
\end{array}$ & 36,000 & Not stated & Activated sludge \\
\hline $\begin{array}{l}\text { Spain (Carballa et al. } \\
\text { 2004) }\end{array}$ & $\begin{array}{l}\text { Ibuprofen }(3.70 ; 1.33) \\
\text { Sulfamethoxazole }(0.58 ; 0.25) \\
\text { Estrone }(0.002 ; 0.004)\end{array}$ & n.a. & 100,000 & Activated sludge \\
\hline $\begin{array}{l}\text { Spain (Radjenović et al. } \\
\text { 2009) }\end{array}$ & $\begin{array}{l}\text { Acetaminophen }(9.90 ; 0.11) \\
\text { Diclofenac }(1.32 ; 1.05) \\
\text { Ibuprofen }(21.7 ; 0.41) \\
\text { Trimethoprim }(0.20 ; 0.12) \\
\text { Erythromycin }(0.82 ; 0.54) \\
\text { Sulfamethoxazole }(0.09 ; 0.02) \\
\text { Metoprolol }(0.04 ; 0.03) \\
\text { Gemfibrozil }(3.08 ; 3.08) \\
\text { Bezafibrate }(14.9 ; 3.01) \\
\text { Carbamazepine }(0.16 ; 0.16)\end{array}$ & 42,000 & Not stated & Activated sludge \\
\hline $\begin{array}{l}\text { Spain (Santos et al. } \\
\text { 2007) }\end{array}$ & $\begin{array}{l}\text { Ibuprofen }(94.1 ; 10.9) \\
\text { Carbamazepine }(0.30 ; 0.50)\end{array}$ & 164,500 & Not stated & Activated sludge \\
\hline
\end{tabular}


Accepted for publication in Science of the Total Environment 622-623 (2018) 1417-1430

\begin{tabular}{|c|c|c|c|c|}
\hline & Caffeine $(2.17 ; 1.24)$ & & & \\
\hline $\begin{array}{l}\text { Switzerland (Tauxe- } \\
\text { Wuersch et al. 2005) }\end{array}$ & $\begin{array}{l}\text { Diclofenac }(1.90 ; 1.90) \\
\text { Ibuprofen }(2.80 ; 0.60)\end{array}$ & 9,300 & 23,000 & $\begin{array}{l}\text { Modified } \\
\text { activated sludge }^{\mathrm{g}}\end{array}$ \\
\hline $\begin{array}{l}\text { Switzerland (Maurer et } \\
\text { al. 2007) }\end{array}$ & Metoprolol $(0.15 ; 0.10)$ & n.a. & 36,000 & $\begin{array}{l}\text { Activated sludge } \\
+ \text { sand filter }\end{array}$ \\
\hline $\begin{array}{l}\text { Finland (Lindqvist et al. } \\
\text { 2005) }\end{array}$ & $\begin{array}{l}\text { Diclofenac }(1.00 ; 0.35) \\
\text { Ibuprofen }(13.3 ; 1.10) \\
\text { Bezafibrate }(0.50 ; 0.33)\end{array}$ & 353,330 & $1,174,000$ & $\begin{array}{l}\text { Modified } \\
\text { activated sludge }^{\mathrm{g}}\end{array}$ \\
\hline $\begin{array}{l}\text { UK (Kasprzyk-Hordern } \\
\text { et al. 2009) }\end{array}$ & $\begin{array}{l}\text { Acetaminophen }(211 ; 11.7) \\
\text { Diclofenac }(0.07 ; 0.10) \\
\text { Ibuprofen }(1.68 ; 0.26) \\
\text { Trimethoprim }(2.19 ; 1.15) \\
\text { Erythromycin }(1.61 ; 1.39) \\
\text { Sulfamethoxazole }(0.03 ; 0.01) \\
\text { Metoprolol }(0.08 ; 0.07) \\
\text { Bezafibrate }(0.42 ; 0.23) \\
\text { Carbamazepine }(1.69 ; 2.50)\end{array}$ & 36,160 & 111,000 & $\begin{array}{l}\text { Trickling filter } \\
\text { beds }\end{array}$ \\
\hline UK (Jones et al. 2007) & $\begin{array}{l}\text { Acetaminophen }(2.00 ; 0.10) \\
\text { Ibuprofen }(4.00 ; 0.50)\end{array}$ & Not stated & 150,000 & Activated sludge \\
\hline UK (Zhou et al. 2009) & $\begin{array}{l}\text { Diclofenac }(0.98 ; 0.08) \\
\text { Sulfamethoxazole }(0.18 ; 0.03) \\
\text { Carbamazepine }(1.83 ; 0.84)\end{array}$ & 34,992 & 32,000 & $\begin{array}{l}\text { Activated sludge } \\
+ \text { sand filter }\end{array}$ \\
\hline $\begin{array}{l}\text { UK (Roberts \& Thomas } \\
\text { 2006) }\end{array}$ & $\begin{array}{l}\text { Acetaminophen }(27.3 ; 0.002) \\
\text { Diclofenac }(0.98 ; 0.34) \\
\text { Ibuprofen }(23.2 ; 12.8) \\
\text { Trimethoprim }(0.26 ; 0.40) \\
\text { Erythromycin }(0.11 ; 0.20)\end{array}$ & 230,000 & Not stated & Activated sludge \\
\hline $\begin{array}{l}\text { Sweden (Zorita et al. } \\
\text { 2009) }\end{array}$ & $\begin{array}{l}\text { Diclofenac }(0.23 ; 0.49) \\
\text { Ibuprofen }(6.90 ; 0.09) \\
\text { Estrone }(0.02 ; 0.07) \\
17 \beta \text {-estradiol }(0.003 ; 0.0025)\end{array}$ & 20,000 & 55,000 & Activated sludge \\
\hline $\begin{array}{l}\text { Sweden (Lindberg et al. } \\
\text { 2005) }\end{array}$ & $\begin{array}{l}\text { Trimethoprim }(0.25 ; 0.22) \\
\text { Sulfamethoxazole }(0.41 ; 0.19)\end{array}$ & $1,400,000$ & 644,000 & $\begin{array}{l}\text { Modified } \\
\text { activated sludge }^{\mathrm{g}}\end{array}$ \\
\hline $\begin{array}{l}\text { Italy (Baronti et al. } \\
\text { 2000) }\end{array}$ & $\begin{array}{l}\text { Estrone }(0.04 ; 0.03) \\
17 \beta \text {-estradiol }(0.01 ; 0.002)\end{array}$ & 734,000 & $1,200,000$ & Activated sludge \\
\hline $\begin{array}{l}\text { Australia (Watkinson et } \\
\text { al. 2007) }\end{array}$ & $\begin{array}{l}\text { Trimethoprim }(0.34 ; 0.05) \\
\text { Sulfamethoxazole }(0.36 ; 0.27)\end{array}$ & 140,000 & 700,000 & Activated sludge \\
\hline $\begin{array}{l}5 \text { activated sludge and } 6 \\
5 \text { conventional activated } \\
10 \text { conventional activated } \\
2 \text { activated sludge plants } \\
\text { chemically enhanced. }\end{array}$ & $\begin{array}{l}\text { dge plants, } 1 \text { modified activate } \\
\text { er plants. } \\
\text { dge plants. } \\
\text { idge plants. } \\
5 \text { other plants. }\end{array}$ & 126010 & & \\
\hline
\end{tabular}

\subsection{Estimation of influx of PPCPs into WWTPs and removal efficiencies}

The estimations in this and the subsequent steps are predicated on the following assumptions:

- the amount of PPCPs in the WWTP influent is directly proportional to the per-capita consumption of PPCP, meaning that a plant serving a larger number of inhabitants will receive a proportionally higher amount of compounds in its influent;

- the consumption of the target compounds is assumed to be constant throughout the year due to a lack of data; although it is acknowledged that some compounds, such as analgesics, are expected to have higher consumption values and, therefore, influx in winter, the seasonal variations will even out over a year; and

- daily variations in the influent volume and any reactions of the compounds in urban effluents before reaching the WWTP are not considered, again due to a lack of data.

The annual per-capita influx of PPCP compounds into a WWTP is estimated as follows, using the relevant data in Table 1 for each WWTP:

$$
I M_{\text {inf }, i}=365 \times 10^{-3} \times\left[\frac{C_{i n f, i} \times Q}{p}\right] \quad \text { (mg/inhab year) }
$$


where:

$\mathrm{IM}_{\mathrm{inf}, \mathrm{i}}$ annual per-capita influx of PPCP compound $i$ into WWTP (mg/inhab year)

$\mathrm{C}_{\text {inf,i }} \quad$ concentration of PPCP compound $i$ in the WWTP influent $(\mu \mathrm{g} / \mathrm{L})$

Q daily wastewater influent into WWTP (L/day)

$\mathrm{p} \quad$ population served by WWTP (number of inhabitants)

The removal efficiency is calculated based on the WWTP influent and effluent concentrations of PPCPs (see Table 1):

$R_{e f f i c i e n c y, i}=\frac{C_{\text {inf }, i}-C_{e f f, i}}{C_{\text {inf }, i}} \times 100$

where:

$\mathrm{R}_{\mathrm{efficiency,i}} \quad$ removal efficiency of PPCP compound $i$ in a WWTP (\%)

$\mathrm{C}_{\mathrm{eff}, \mathrm{i}} \quad$ concentration of PPCP compound $i$ in the effluent of a WWTP $(\mu \mathrm{g} / \mathrm{L})$.

In addition to the influent concentrations, the removal efficiency is influenced by the design and operation of WWTPs, which in turn affect the concentration of the compounds in the effluent (Clara et al. 2005, Ratola et al. 2012). To account for the variation in different parameters, the expected concentration ranges for each PPCP compound in the WWTP influent and effluent are considered in step 3, as detailed in the next section.

\subsection{Estimation of concentration ranges of PPCP compounds in WWTPs}

The box plot method is used to determine the expected influent and effluent ranges for the PPCP compounds, due to its non-parametric nature. For these purposes, the values for $I M_{\text {inf }, i}$ and $R_{\text {efficiency, } i \text {, }}$ estimated in the previous step for each compound and WWTP in Table 1, are grouped into two datasets (A and B), respectively. Each dataset is then divided into four equal quartiles, each containing a quarter of the data. Then, the first quartile is defined as the middle (median) value between the lowest and the median value of the data set, the second quartile as the median of the data set and the third quartile as the middle value between the highest and the median value of the data set. The interquartile range, defined as the difference between the third (upper) and first (lower) quartile, assumes that the values will be bundled around a central (or median) value, as per the box-plot method. As a result, the interquartile range is considered to be representative of the whole dataset for each PPCP compound if it contains more than 50\% of values (Potter 2006). The interquartile range can also be used to define outliers, i.e. the values too far from the central value or the expected range. Here, the high and low outliners are defined, respectively, as those 1.5 times above the upper quartile value and 1.5 times below the lower quartile value, following the box-plot method. Accordingly, the daily influx range for each PPCP compound can be estimated as:

$\alpha_{\text {range }, i}=\frac{\lambda_{\text {range }, i}}{365 \times 10^{3}} \times p \quad \lambda_{\text {range }, i} \subseteq A \quad$ (g/day)

where:

$\alpha_{\text {range,i }}$ estimated daily influx range for compound $i$ in WWTP (g/day)

$\lambda_{\text {range, } i} I M_{i n f, i}$ value for compound $i$ within the interquartile range (mg/inhab year)

A dataset of $I M_{\text {inf }, i}$ values (mg/inhab year).

The influent concentration range $\beta_{\text {range, } i}$ in a WWTP is calculated according to:

$\beta_{\text {range }, i}=\frac{10^{3}}{365} x \frac{\lambda_{\text {range }, i}}{q} \quad \lambda_{\text {range }, i} \subseteq A \quad(\mu \mathrm{g} / \mathrm{L})$ 
where:

$\beta_{\text {range, } i}$ estimated influent concentration range for PPCP compound $i(\mu \mathrm{g} / \mathrm{L})$

q average per-capita daily wastewater influent into WWTP (L/inhab day).

The expected range of removal efficiencies $R_{\text {range }, i}$ for each PPCP compound $i$ is determined using dataset $\mathrm{B}$, where $R_{\text {range, } i}$ represents the interquartile range of $R_{\text {efficiency, } i}$ values (\%).

Therefore, the effluent concentration range for PPCP compound $i$ can be estimated according to:

$\gamma_{\text {range }, i}=\beta_{\text {range }, i} x\left(R_{\text {range }, i} x 10^{-2}\right) \quad R_{\text {range }, i} \subseteq B \quad(\mu \mathrm{g} / \mathrm{L})$

where

$\gamma_{\text {range,i }}$ estimated effluent concentration range for PPCP compound $i(\mu \mathrm{g} / \mathrm{L})$

B dataset of $R_{\text {efficiency, } i}$ values (\%).

The concentration range of PPCP compounds retained by the sludge can be estimated using the solid-water distribution coefficient and the sludge solids content (Verlicchi \& Zambello 2015):

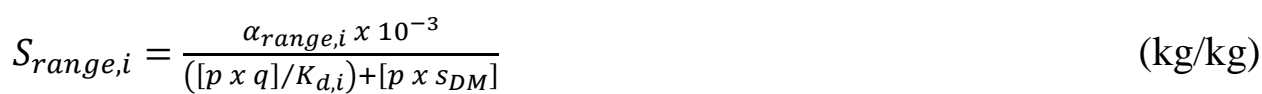

where:

$\mathrm{S}_{\text {range, } i}$ concentration range of compound $i$ in the sludge $(\mathrm{kg} / \mathrm{kg})$

$\mathrm{K}_{\mathrm{d}, \mathrm{i}} \quad$ solid-water distribution coefficient of compound $i(\mathrm{~L} / \mathrm{kg})$

$\mathrm{S}_{\mathrm{DM}} \quad$ per-capita amount of dry matter in the sludge ( $\mathrm{kg} /$ inhab day)

$10^{-3}$ conversion from $\mathrm{g}$ to $\mathrm{kg}$.

2.4. Estimation of freshwater concentrations of PPCP compounds

Finally, using the values estimated in the previous steps, the predicted freshwater concentration of the target PPCP compounds after the release of the WWTP effluent can be estimated according to the following equation:

$P E C_{\text {range }, i}=\gamma_{\text {range }, i}\left[\frac{p \times q}{F+(p \times q)}\right] \quad \quad(\mu \mathrm{g} / \mathrm{L})$

where:

$\mathrm{PEC}_{\text {range,i }} \quad$ predicted environmental concentration range of compound $i$ in freshwater after the release of WWTP effluent $(\mu \mathrm{g} / \mathrm{L})$

F daily flow of a freshwater body (L/day).

The estimate of PEC is based on the following assumptions: there is no previous PPCP contamination of a freshwater body; there is no prompt degradation of PPCP compounds after the effluent discharge; and spatial and time variations in the concentration of the target compounds are homogeneous.

\section{Results and discussion}

3.1. Selection of target PPCP compounds and data collection

As can be seen in Table 1, the data for the influent flow $Q$ and the served population $p$ range widely. For example, the smallest treatment facility has an average flow of $7,200 \mathrm{~m}^{3} /$ day and the largest $2,785,000 \mathrm{~m}^{3} /$ day; the population served varies from 23,000 to 6.1 million. However, as indicated in Figure 1, the influent flow and the population served are well correlated linearly $\left(\mathrm{R}^{2}=\right.$ 0.9225). Based on these data, the average per-capita influent flow $q$ is equivalent to 428 
L/inhab day. This value is used for the estimations of different parameters in the next steps. Using the average $q$, estimated based on multiple data points from small to large WWTPs, decreases the influence of the variations in daily and seasonal flows, in industrial and storm water contributions to the influent flow and, consequently, in PPCP concentrations. While the estimated value is greater than the average in Europe (150-200 L/inhab./day), it is within the range in the US, Canada and Australia (400-500 L/inhab./day). Since the data include these regions and Asian countries, combined with the fact that many of the considered WWTPs also treat storm water (Environmental Agency 2008; Sperling 2007), this value is arguably representative.

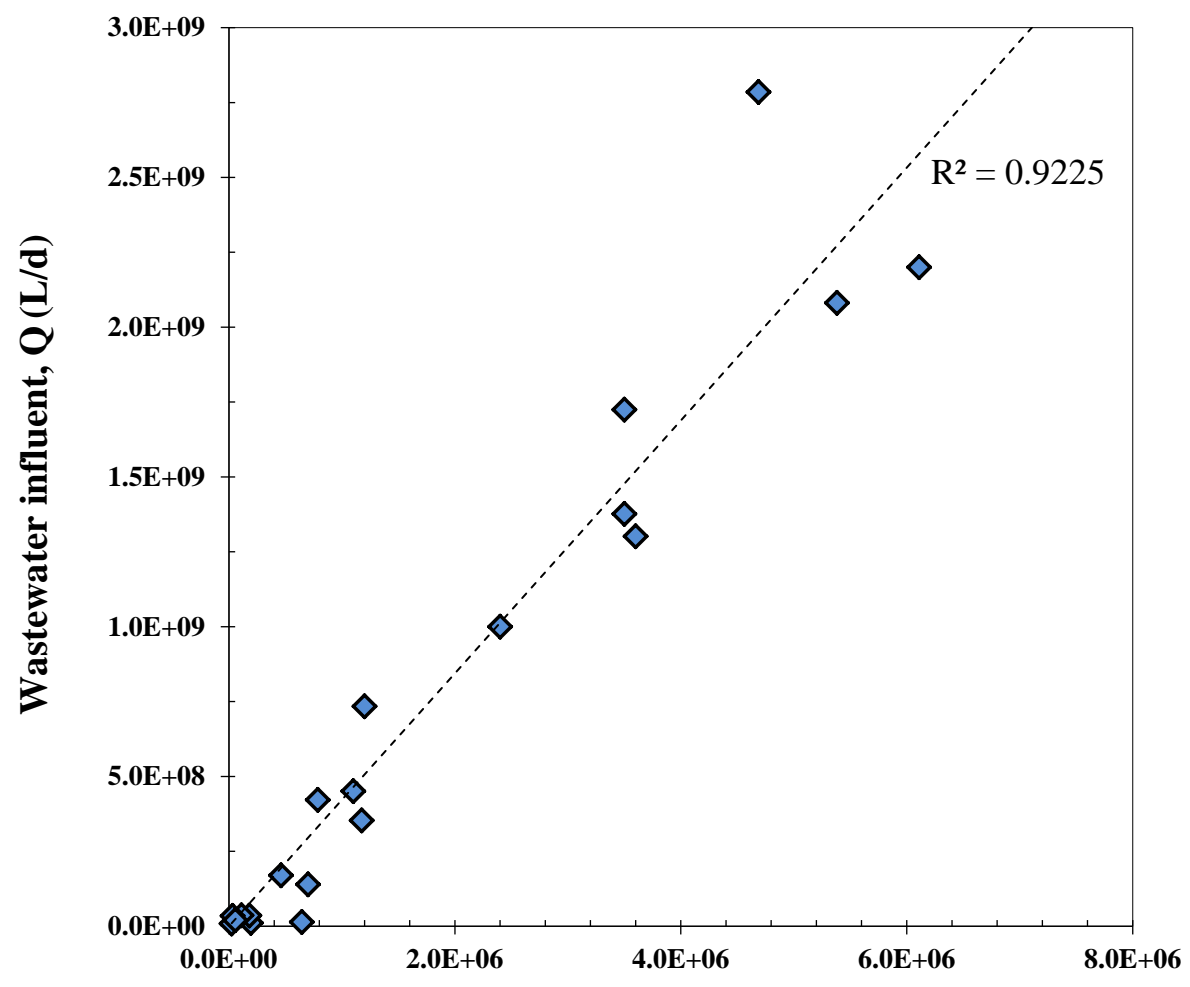

Population served, p (no. of inhabitants)

Figure 1 Correlation between daily water influent $Q$ and population $p$ served by WWTP based on the data in Table 1 .

\subsection{Estimation of influx of PPCPs into WWTPs and removal efficiency}

The annual per-capita influx $I M_{\text {inf }, i}$ into WWTPs of the target PPCPs and their removal efficiencies

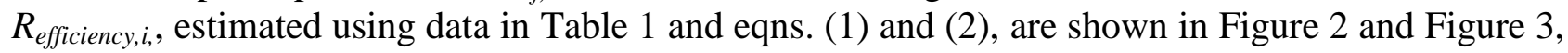
respectively. As can be seen in Figure 2, the great majority of the $I M_{i n f, i}$ values fall between 1 and $100 \mathrm{mg} / \mathrm{inhab}$ year, with only three being above 1,000 and three below $1 \mathrm{mg} / \mathrm{inh}$ ab year. Similarly, most of the removal efficiencies $R_{\text {efficiency,i,s }}$ in Figure 3 vary between $20 \%$ and $100 \%$, with only a few falling below $20 \%$. It can also be observed that removal efficiencies for some compounds have negative values - this is due either to their accumulation (Gao et al. 2012, Katsoyiannis \& Samara 2005, Li \& Zhang 2011, Quintana et al. 2005) or chemical reactions during the treatment process (Carballa et al. 2004, Esperanza et al. 2007, Schlüsener \& Bester 2008, Xu et al. 2012) which can lead to higher concentrations in the effluent than in the influent.

The estimated $I M_{\text {inf }, i}$ and $R_{\text {efficiency, } i}$ values are then grouped respectively into the datasets A and B for each target compound (see Tables S1 and S2 in the Supplementary Information (SI)) to determine the interquartile values and the outliers. The latter, summarised in Table 2, are excluded from further consideration. It can be noticed in Table 2 that there are only four outliers for $I M_{\text {inf, } i \text {, out of }}$ 85 data points in total. All of these are for the WWTPs based in the UK, with one being shared with Switzerland. Given that consumption of PPCPs in the UK is amongst the highest in the world 
Accepted for publication in Science of the Total Environment 622-623 (2018) 1417-1430

(WHO 2004), this would suggest that higher consumption leads to their higher influx into WWTPs (Lindqvist et al. 2005, Oosterhuis et al. 2013, Zhang \& Geißen 2010).

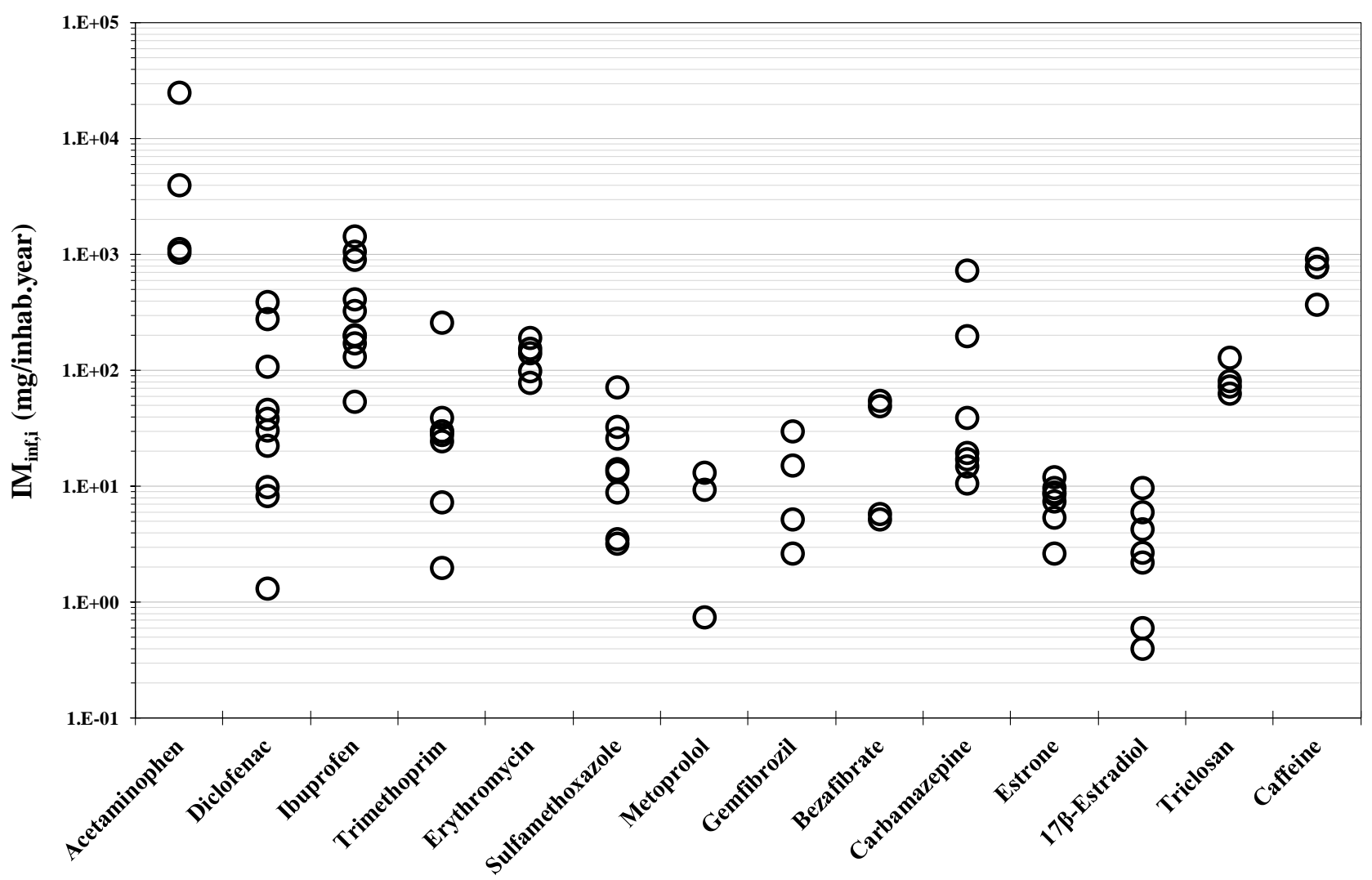

Figure 2 Annual per-capita discharge $I M_{i n f, i}$ of target PPCP compounds estimated using eqn. (1) and data from Table 1. Each point on the graph represents $I M_{i n f}$ for one target compound $i$. 


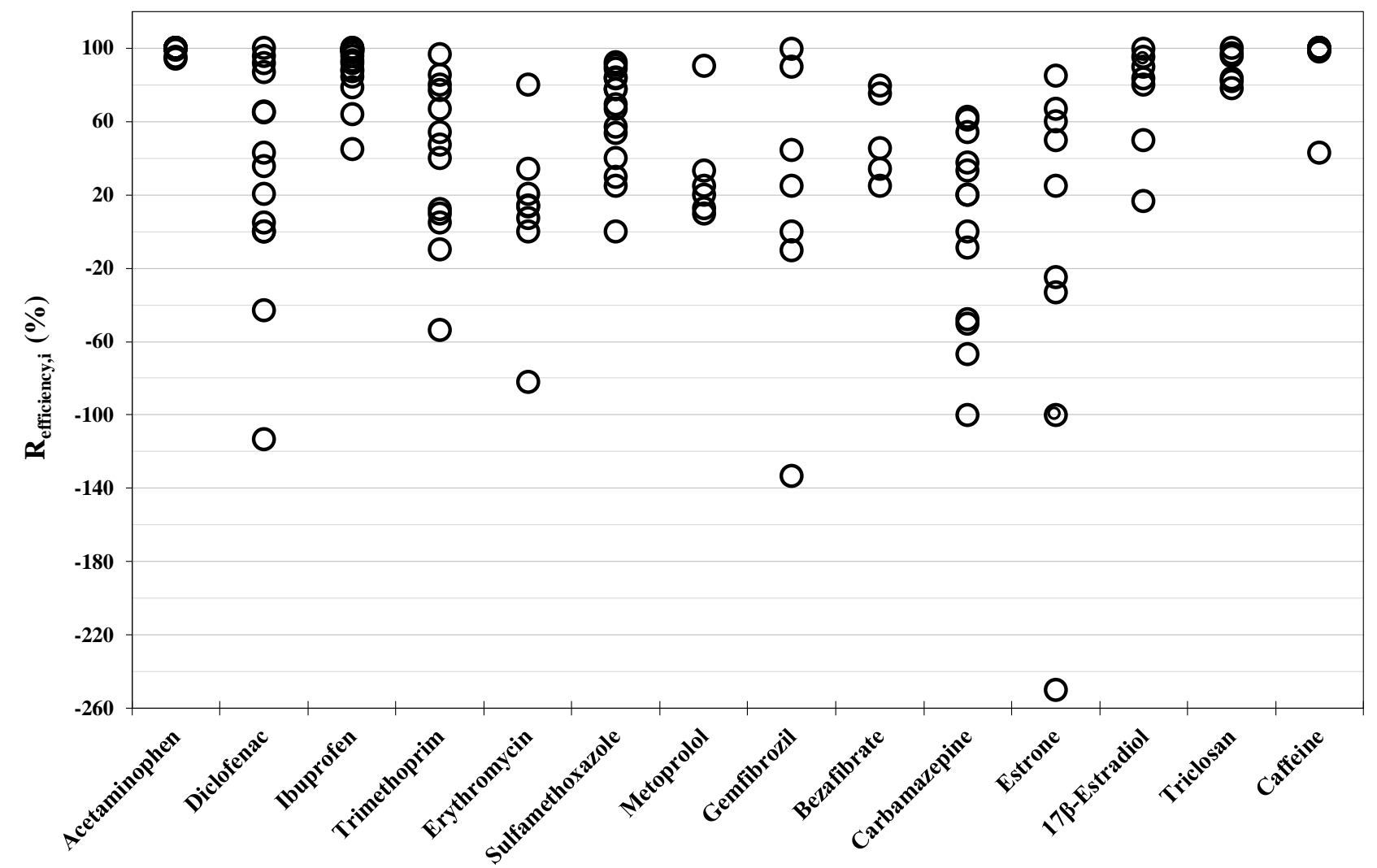

Figure 3 Removal efficiencies $R_{\text {efficiency, } i}$ for target PPCP compounds estimated using eqn. (2) and data from Table 1. Each point in the graph represents $R_{\text {efficiency }}$ for one target compound $i$.

For the removal efficiencies (dataset B in Table 2), out of 142 data points, 10 are outliers, with the majority being for the WWTPs in the UK and Spain. However, no correlation is apparent between the number of outliers and the type of WWTP or operational parameters (for the latter two, see Table 1), despite a wide range covered by the data in the literature.

Table 2 Outliers for the influx of PPCP compounds (A dataset) and removal efficiencies (dataset B) in WWTPs

\begin{tabular}{|c|c|c|c|c|c|}
\hline Compound $i$ & WWTP location & $\begin{array}{c}\text { Dataset } \mathrm{A}, I M_{\text {inf }, i} \\
\text { (mg/inhabyear) }\end{array}$ & $\begin{array}{l}\text { Total number } \\
\text { of data points }\end{array}$ & $\begin{array}{c}\text { Dataset B, } \boldsymbol{R}_{\text {efficiency }, i} \\
(\%)\end{array}$ & $\begin{array}{l}\text { Total number } \\
\text { of data points }\end{array}$ \\
\hline Acetaminophen & UK & $-^{\mathrm{a}}$ & 4 & $94.45 ; 95.00$ & 10 \\
\hline Diclofenac & UK & 391.14 & 10 & - & 14 \\
\hline Ibuprofen & Spain; UK & - & 10 & $44.83 ; 64.05$ & 18 \\
\hline Trimethoprim & UK & 260.40 & 8 & - & 13 \\
\hline Erythromycin & South Korea; UK & - & 5 & $-81.82 ; 80.00$ & 8 \\
\hline Sulfamethoxazole & UK & 71.84 & 8 & - & 15 \\
\hline Metoprolol & US & - & 3 & 90.48 & 6 \\
\hline Gemfibrozil & Spain & - & 4 & -133.33 & 7 \\
\hline Bezafibrate & - & - & 4 & - & 5 \\
\hline Carbamazepine & UK & 730.40 & 7 & - & 13 \\
\hline Estrone & - & - & 7 & - & 10 \\
\hline $17 \beta$-estradiol & Sweden & - & 7 & 16.67 & 8 \\
\hline Triclosan & - & - & 4 & - & 6 \\
\hline Caffeine & Spain & - & 4 & 42.86 & 9 \\
\hline
\end{tabular}

\footnotetext{
${ }^{a}$ One of the values was much higher than the rest (see Table S1 in Supplementary information), but due to a small data sample, that value has not been considered as an outlier.
} 
Accepted for publication in Science of the Total Environment 622-623 (2018) 1417-1430

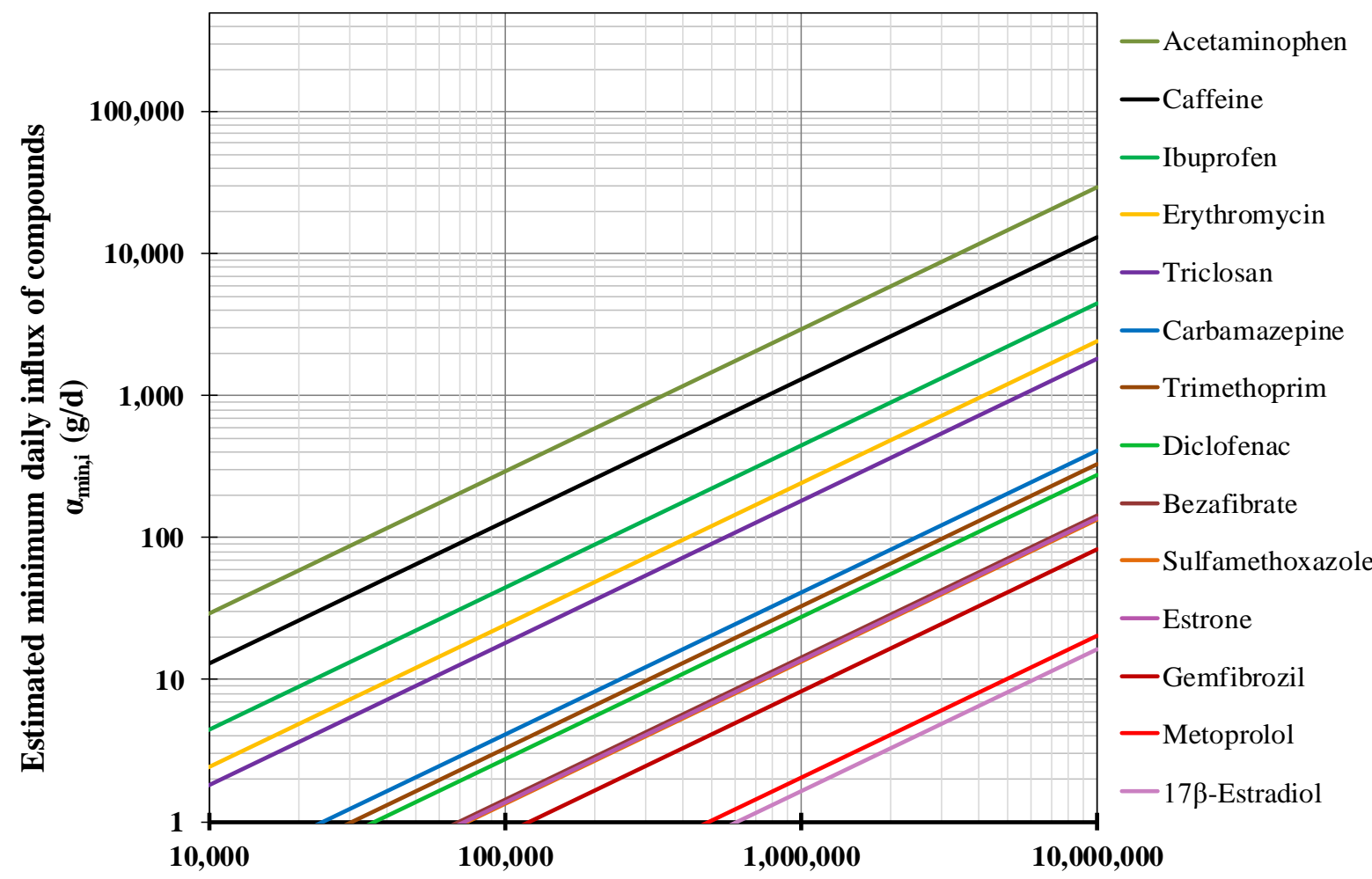

Population served by the plant, p (no. of inhabitants)

a) Minimum daily influx

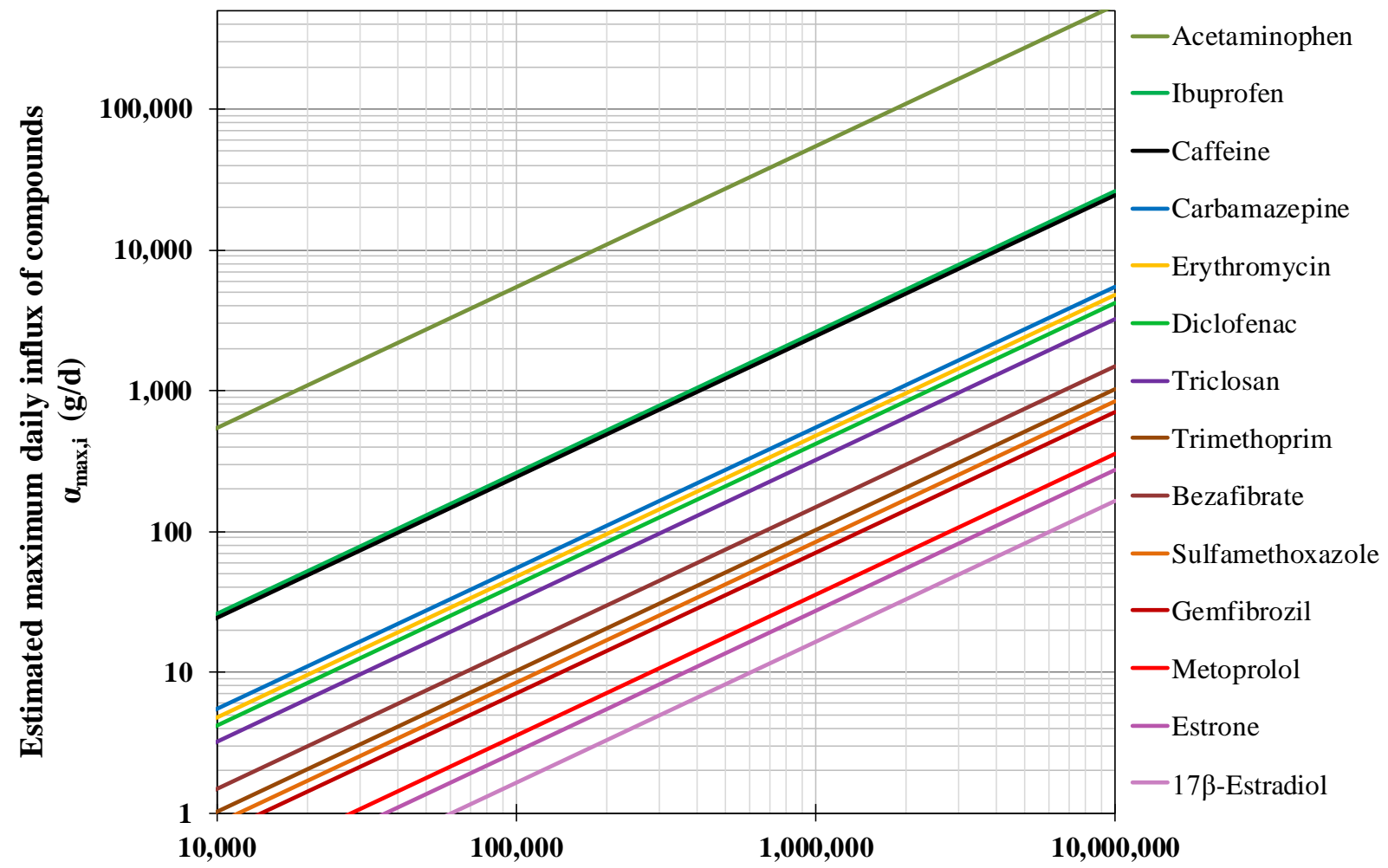

Population served by the plant, $p$ (no. of inhabitants)

b) Maximum daily influx

Figure 4 Minimum (a) and maximum (b) daily influx of target PPCPs estimated according to eqn. (3) for different size of the population served by WWTPs. 


\subsection{Estimation of concentration ranges of PPCP compounds in WWTPs}

\subsubsection{Daily influx ranges}

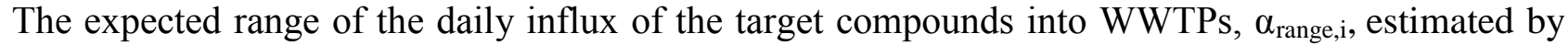
eqn. (3) is given in Figure 5; for further details, see Table S3 in SI. The figure shows minimum (Figure 5a) and maximum (Figure 5b) values, taking into account the size of the population $p$ served by WWTP. As can be seen, the expected daily influx of PPCP compounds is correlated linearly with the size of the population. This is in congruence with the assumption discussed in the previous section that a greater per-capita consumption of PPCPs leads to a higher influx of their compounds into WWTPs. For example, it can be inferred from Figure 4Figure 5 that a WWTP serving 200,000 inhabitants has an expected daily influx of acetaminophen in the range of 600 $\mathrm{g} /$ day to $10 \mathrm{~kg} /$ day while that serving twice as many people can expect double the influx.

The PPCP compound with the highest estimated influx is acetaminophen, followed by ibuprofen and caffeine. This is not surprising since all three products are available over the counter and used widely. The lowest influx is found for the hormones $17 \beta$-estradiol and estrone.

\subsubsection{Influent concentration ranges}

The influent concentration range of PPCP compounds in a WWTP, $\beta_{\text {range, },}$, calculated according to eqn. (4) for the average per-capita influent of $428 \mathrm{~L} / \mathrm{inh}$ abday, is given in Table 3 . As can be seen, the expected mean concentration for most compounds ranges between $0.02 \mu \mathrm{g} / \mathrm{L}$ for $17 \beta$-estradiol to $66.9 \mu \mathrm{g} / \mathrm{L}$ for acetaminophen. In the worst case, the latter can reach $127 \mu \mathrm{g} / \mathrm{L}$; the next worst are ibuprofen with $6.1 \mu \mathrm{g} / \mathrm{L}$ and caffeine at $5.7 \mu \mathrm{g} / \mathrm{L}$. The lowest minimum concentrations can be expected for metoprolol and $17 \beta$-estradiol $(0 \mu \mathrm{g} / \mathrm{L}$ or below detection levels $)$.

Table 3 Estimated influent concentration ranges for the target PPCP compounds ${ }^{\mathrm{a}}$

\begin{tabular}{|c|c|c|c|c|}
\hline \multirow{2}{*}{ Compound $i$} & \multicolumn{3}{|c|}{$\boldsymbol{\beta}_{\text {range, }}(\mu \mathrm{g} / \mathrm{L})$} & \multirow{2}{*}{$\begin{array}{c}\text { Variation }\left(\boldsymbol{\beta}_{\text {max,i }}-\boldsymbol{\beta}_{\text {min, }, \mathbf{i}}\right) \\
(\mu \mathrm{g} / \mathrm{L})\end{array}$} \\
\hline & $\beta_{\min , \mathrm{i}}$ & $\beta_{\text {mean }, \mathbf{i}}$ & $\beta_{\max , \mathbf{i}}$ & \\
\hline Acetaminophen & 6.87 & 66.9 & 127 & 120 \\
\hline Diclofenac & 0.06 & 0.52 & 0.97 & 0.91 \\
\hline Ibuprofen & 1.04 & 3.57 & 6.10 & 5.06 \\
\hline Trimethoprim & 0.08 & 0.16 & 0.24 & 0.16 \\
\hline Erythromycin & 0.57 & 0.84 & 1.11 & 0.54 \\
\hline Sulfamethoxazole & 0.03 & 0.11 & 0.20 & 0.17 \\
\hline Metoprolol & 0.00 & 0.04 & 0.08 & 0.08 \\
\hline Gemfibrozil & 0.02 & 0.09 & 0.17 & 0.15 \\
\hline Bezafibrate & 0.03 & 0.19 & 0.35 & 0.31 \\
\hline Carbamazepine & 0.10 & 0.69 & 1.29 & 1.19 \\
\hline Estrone & 0.03 & 0.05 & 0.06 & 0.03 \\
\hline $17 \beta$-estradiol & 0.00 & 0.02 & 0.04 & 0.03 \\
\hline Triclosan & 0.42 & 0.59 & 0.76 & 0.33 \\
\hline Caffeine & 3.06 & 4.40 & 5.74 & 2.68 \\
\hline
\end{tabular}

\subsubsection{Expected removal ranges}

To estimate the expected concentration range $\gamma_{\text {range, } i}$ of PPCPs in the WWTP effluent (eqn. (5)), it was first necessary to determine the expected range of removal efficiencies $R_{\text {range, } i}$ for each compound using dataset B (see Table S2 in SI). As shown in Figure 5 and Table S4, the expected removal efficiencies vary greatly with the lowest removal $(\leq 25 \%)$ expected for erythromycin, metoprolol, carbamazepine and estrone and the highest $(>90 \%)$ for acetaminophen, ibuprofen and caffeine. For some compounds (gemfibrozil, carbamazepine and estrone), negative removal efficiencies can be expected resulting in a higher concentration in the effluent than in the influent into WWTP. As mentioned earlier, this is due to possible transformation, recombination and/or accumulation of the compounds during the secondary treatment (Gao et al. 2012, Kagle et al. 2009, Verlicchi et al. 2012). For instance, among the PPCPs, carbamazepine has the lowest sorption and 
biodegradability in wastewater treatments (Clara et al. 2004, Onesios et al. 2009, Ying et al. 2009). Estrone also has an unpredictable behaviour owing to an irregular sorption potential, dependence on the oxidation conditions and microbial activity in biological treatment (Atkinson et al. 2012, Esperanza et al. 2007, Evgenidou et al. 2014, Koh et al. 2008). By contrast, the lowest variation in the removal efficiencies $(\leq 1 \%)$ was found for caffeine and acetaminophen, suggesting that their removal is not dependent on the type of treatment or operating conditions of the plant.

However, the variation in the removal efficiencies could also be attributed to a wide variation in their physicochemical properties which can impair their removal by conventional wastewater treatment methods (Daughton \& Ternes 1999, Jelic et al. 2011, Onesios et al. 2009, Ying et al. 2009). To examine the possible effects of this, some physicochemical properties of the target compounds were considered in relation to their removal efficiencies estimated here. As shown in Table 4 and Figures S2 and S3 in the SI, the acidic compounds were found to have moderate removal efficiencies (30\%-62.5\%) and removal variations (35-80\%), with ibuprofen being the only exception. The basic compounds exhibited more extreme mean removal efficiencies (lower than $22.5 \%$ or higher than $80 \%)$ and the removal variation $(<30 \%$ and $>80 \%)$. These observations are in agreement with the findings by other authors related to the behaviour of acidic PPCPs during biological treatment and their presence in the environment (Metcalfe et al. 2003, Quintana et al. 2005, Thomas \& Foster 2005, Wang et al. 2010).

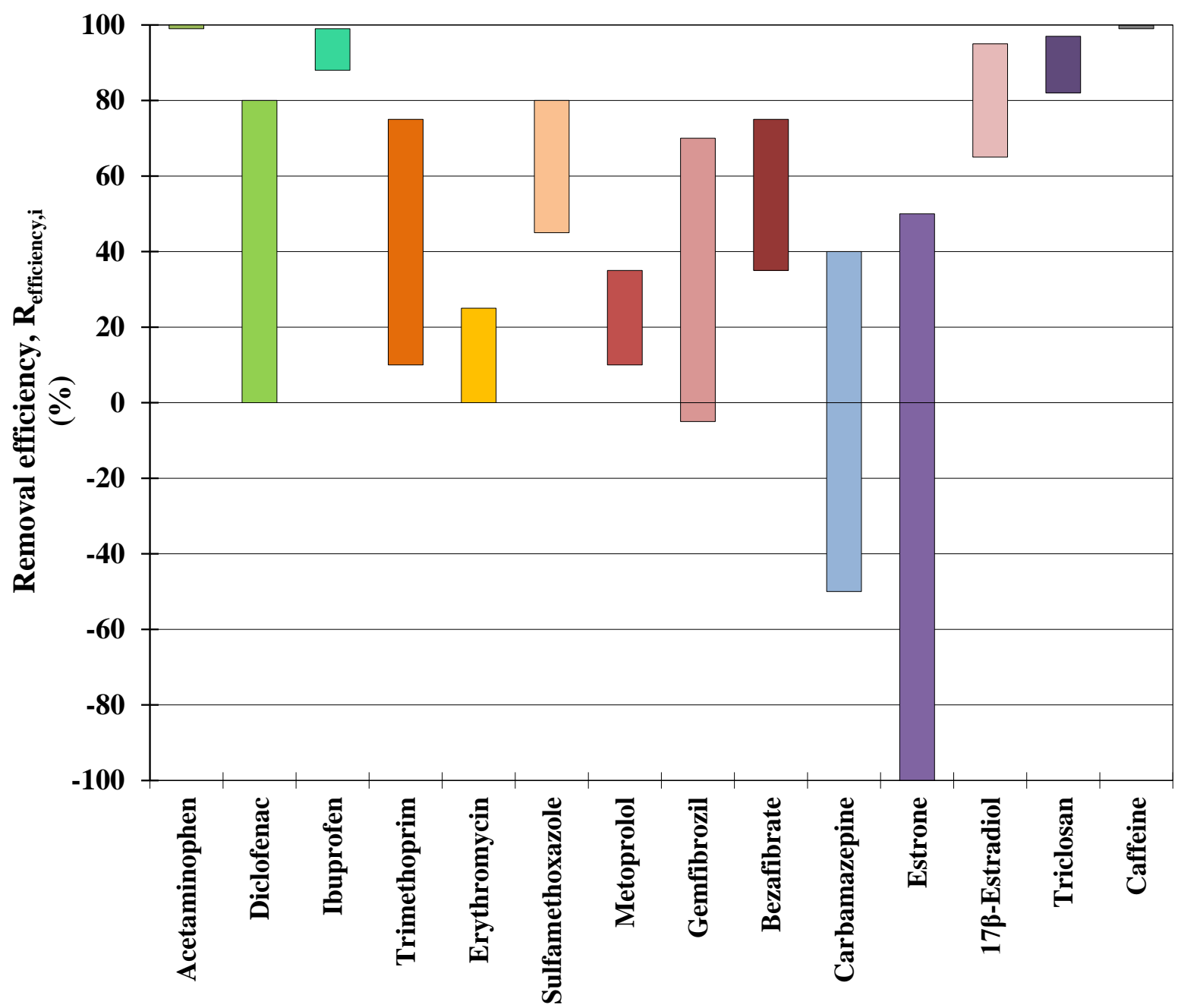

Figure 5 - Estimated range of WWTP removal efficiencies $\left(\mathrm{R}_{\mathrm{range}, \mathrm{i}}\right)$ for the target compounds. 
Accepted for publication in Science of the Total Environment 622-623 (2018) 1417-1430

Table 4 - Estimated removal efficiencies of the target PPCPs based on their physicochemical properties

\begin{tabular}{|c|c|c|c|c|c|c|}
\hline Compound $i$ & $\begin{array}{l}\mathbf{M W}^{\mathbf{a}} \\
(\mathrm{g} / \mathrm{mol})\end{array}$ & $\log K_{\text {ow }}^{a}$ & $\mathbf{p K}_{\mathrm{a}}^{\mathrm{a}}$ & $\begin{array}{c}\mathbf{K}_{\mathbf{d}} \\
(\mathrm{L} / \mathrm{kg})\end{array}$ & $\begin{array}{c}\text { Mean removal efficiency, } \\
\boldsymbol{R}_{\text {mean }, i}(\%)\end{array}$ & $\begin{array}{l}\text { Removal efficiency } \\
\text { variation }(\%)\end{array}$ \\
\hline Carbamazepine & 236.27 & 2.45 & 13.90 & $135.0^{\mathrm{c}}$ & -5.00 & 90.0 \\
\hline Bezafibrate & $361.83^{\mathrm{b}}$ & $4.30^{\mathrm{b}}$ & $3.60^{\mathrm{b}}$ & - & 55.00 & 40.0 \\
\hline Diclofenac & 296.15 & 0.70 & 4.20 & $118.0^{\mathrm{c}}$ & 40.00 & 80.0 \\
\hline Ibuprofen & 206.23 & 3.97 & 4.90 & $227.51^{\mathrm{d}}$ & 93.50 & 11.0 \\
\hline Gemfibrozil & 250.34 & 4.77 & 4.70 & $19.30^{\mathrm{c}}$ & 30.00 & 70.0 \\
\hline Sulfamethoxazole & 253.28 & 0.89 & 5.70 & $77.00^{\mathrm{c}}$ & 62.50 & 35.0 \\
\hline Trimethoprim & 290.30 & 0.91 & 6.80 & $253.00^{\mathrm{c}}$ & 42.50 & 65.0 \\
\hline Triclosan & 289.55 & 4.76 & 7.80 & $8,600.0^{\mathrm{e}}$ & 89.50 & 15.0 \\
\hline Erythromycin & $733.95^{b}$ & $3.10^{\mathrm{b}}$ & $8.90^{\mathrm{b}}$ & $74.00^{\mathrm{c}}$ & 12.50 & 25.0 \\
\hline Acetaminophen & 151.17 & 0.46 & 9.40 & $0.42^{\mathrm{d}}$ & 99.49 & 1.00 \\
\hline Metoprolol & 267.30 & 2.15 & 9.60 & - & 22.50 & 25.0 \\
\hline $17 \beta$-estradiol & 272.20 & 4.01 & 10.34 & $354.81^{\mathrm{f}}$ & 80.00 & 30.0 \\
\hline Caffeine & 194.19 & -0.07 & 10.40 & $19.00^{\mathrm{g}}$ & 99.45 & 0.90 \\
\hline Estrone & 270.40 & 3.13 & 10.46 & $293.00^{\mathrm{f}}$ & -25.00 & 150 \\
\hline $\begin{array}{l}\text { MW: molecular } \\
\text { coefficient. } \\
{ }^{\text {a }} \text { Behera et al. (201 } \\
{ }^{\mathrm{b}} \text { Muñoz et al. (20 } \\
{ }^{\mathrm{c}} \text {. Radjenović et al. } \\
{ }^{\mathrm{d}} \text { StuerLauridsen e } \\
{ }^{\mathrm{e}} \text { Stasinakis et al. ( } \\
{ }^{\mathrm{f}} \text { Carballa et al. (2 } \\
{ }^{\mathrm{g}} \text { Karnjanapiboony }\end{array}$ & $\begin{array}{l}09) \\
(2000) \\
0)\end{array}$ & anol-water & rtition & oefficients & $\mathrm{pK}_{\mathrm{a}}$ : acid dissociation cons & $\mathrm{K}_{\mathrm{d}}:$ solid-water distri \\
\hline
\end{tabular}

Table 5 Estimated effluent concentration ranges for the target PPCP compounds ${ }^{\mathrm{a}}$

\begin{tabular}{|c|c|c|c|c|}
\hline \multirow{2}{*}{ Compound $i$} & \multicolumn{3}{|c|}{$\gamma_{\text {range, }, i}(\mu \mathrm{g} / \mathrm{L})$} & \multirow{2}{*}{$\begin{array}{c}\text { Variation }\left(\gamma_{\text {max }, i}-\gamma_{\min , \mathbf{i}}\right) \\
(\mu \mathrm{g} / \mathrm{L})\end{array}$} \\
\hline & $\gamma_{\min , i}$ & $\gamma_{\text {mean,i }}$ & $\gamma_{\max , i}$ & \\
\hline Acetaminophen & 0.00 & 0.64 & 1.28 & 1.28 \\
\hline Diclofenac & 0.01 & 0.49 & 0.97 & 0.96 \\
\hline Ibuprofen & 0.01 & 0.37 & 0.73 & 0.72 \\
\hline Trimethoprim & 0.02 & 0.12 & 0.21 & 0.19 \\
\hline Erythromycin & 0.43 & 0.77 & 1.11 & 0.68 \\
\hline Sulfamethoxazole & 0.01 & 0.06 & 0.11 & 0.10 \\
\hline Metoprolol & 0.00 & 0.04 & 0.07 & 0.07 \\
\hline Gemfibrozil & 0.01 & 0.09 & 0.17 & 0.17 \\
\hline Bezafibrate & 0.01 & 0.12 & 0.22 & 0.22 \\
\hline Carbamazepine & 0.06 & 0.99 & 1.93 & 1.87 \\
\hline Estrone & 0.02 & 0.07 & 0.13 & 0.11 \\
\hline $17 \beta$-estradiol & 0.002 & 0.008 & 0.013 & 0.011 \\
\hline Triclosan & 0.01 & 0.07 & 0.14 & 0.12 \\
\hline Caffeine & 0.00 & 0.03 & 0.06 & 0.05 \\
\hline
\end{tabular}

\subsubsection{Effluent concentration ranges}

The expected concentration range $\gamma_{\text {range, } i}$ of PPCPs in the WWTP effluent, estimated by using the influent concentration and the removal efficiency ranges (eqn. (5)), are summarised in Table 5. The results suggest that, similar to the influent concentrations, the minimum mean effluent concentration is expected for $17 \beta$-estradiol $(0.008 \mu \mathrm{g} / \mathrm{L})$. However, unlike the influent concentrations, the highest mean effluent value was found for carbamazepine $(0.99 \mu \mathrm{g} / \mathrm{L})$; this is due to its accumulation and inefficient removal in WWTPs.

\subsubsection{Sludge concentration ranges}

The concentration ranges $S_{\text {range, } i}$ of the target PPCP compounds in the sludge from WWTPs, calculated according to eqn. (6), are given in Figure 6 and Table S5 in the SI. Following the trend for the influent concentrations, the highest mean concentrations in the sludge are expected for triclosan and ibuprofen (2,526.38 and $791.62 \mu \mathrm{g} / \mathrm{kg}$, respectively) and the lowest for sulfamethoxazole, 17 $\beta$-estradiol, and gemfibrozil (all below a mean concentration of $9 \mu \mathrm{g} / \mathrm{kg}$ ). 
These results are in broad agreement with previous estimates. For instance, according to the findings by McClellan \& Halden (2010), triclosan, erythromycin, caffeine and ibuprofen were found at the highest concentration in 94 wastewater treatment plants in the district of Columbia, US. This is in accordance with the present work, where these three compounds have the highest mean concentrations. Although triclosan in McClellan \& Halden (2010) had a much higher mean concentration $(10,000 \mu \mathrm{g} / \mathrm{kg})$, caffeine, ibuprofen, erythromycin, trimethoprim and sulfamethoxazole were in the same range as calculated here. The results for these and the other compounds obtained in this work are also in agreement with the ranges obtained in the literature (Petrovic et al. 2009, Verlicchi \& Zambello 2015). The only exception was found to be gemfibrozil which appears to be underestimated in the current work. This is possibly due to its recalcitrant behaviour, as noted by some other authors who reported its variable sorption in sewage sludge (Radjenović et al. 2009, Ying et al. 2009).

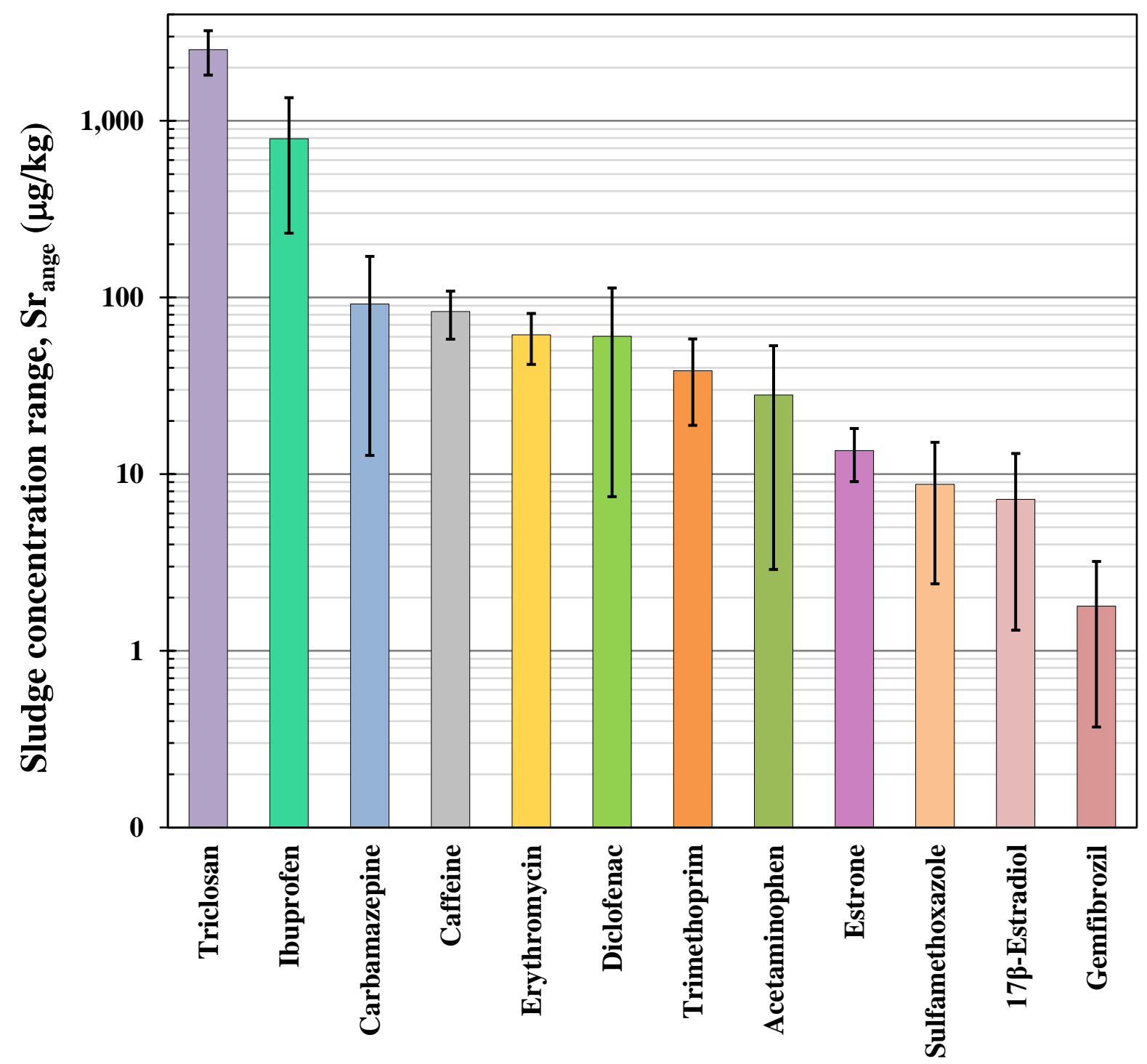

Figure 6 Estimated sludge concentration ranges $\left(\mathrm{S}_{\text {range, },}\right)$ for the target PPCP compounds.

(Values calculated from eq. (6) and $\mathrm{K}_{\mathrm{d}}$ values from Table 4 ; $\mathrm{q}=428 \mathrm{~L} / \mathrm{inhab}$.day and $\mathrm{s}_{\mathrm{DM}}=50 \mathrm{~g} / \mathrm{inh}$ ab.day) 
Accepted for publication in Science of the Total Environment 622-623 (2018) 1417-1430

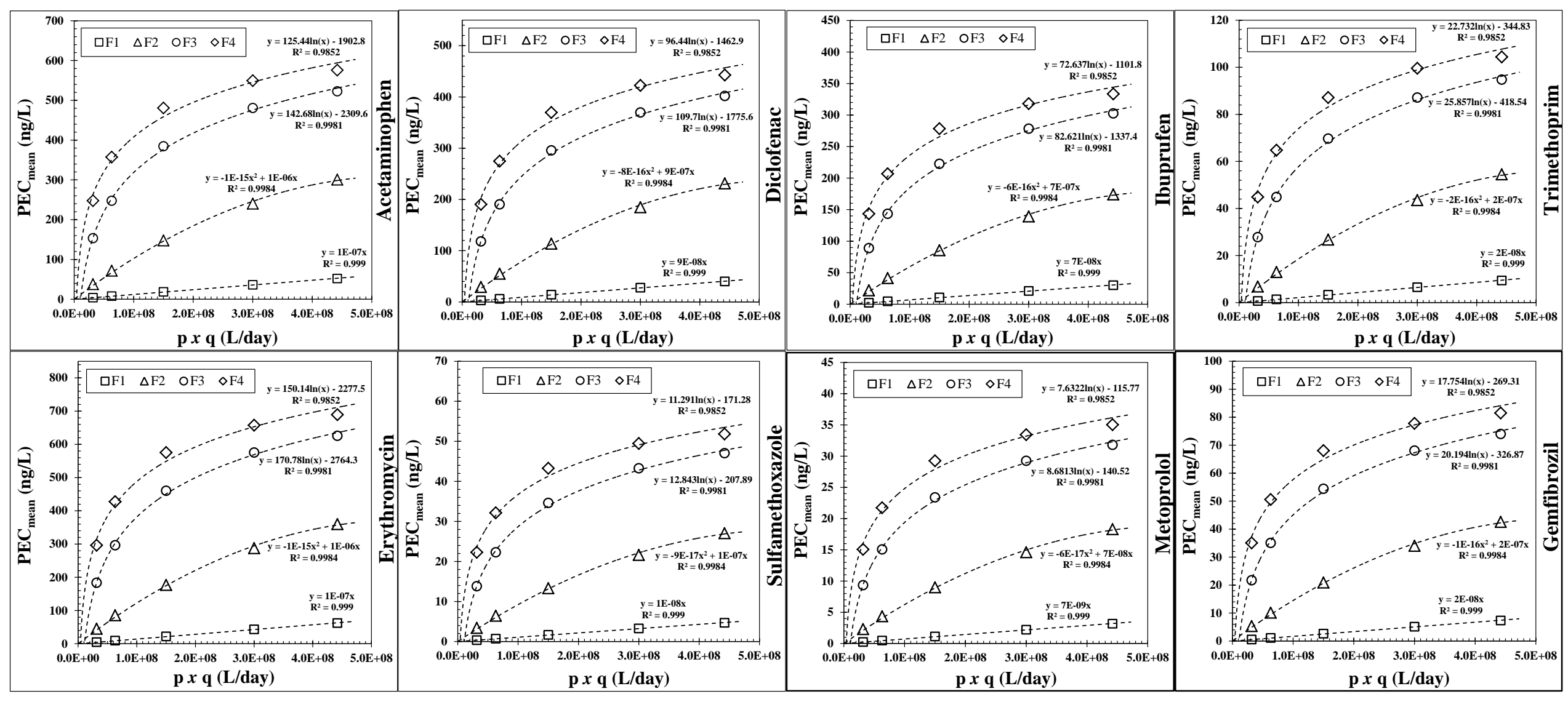


Accepted for publication in Science of the Total Environment 622-623 (2018) 1417-1430
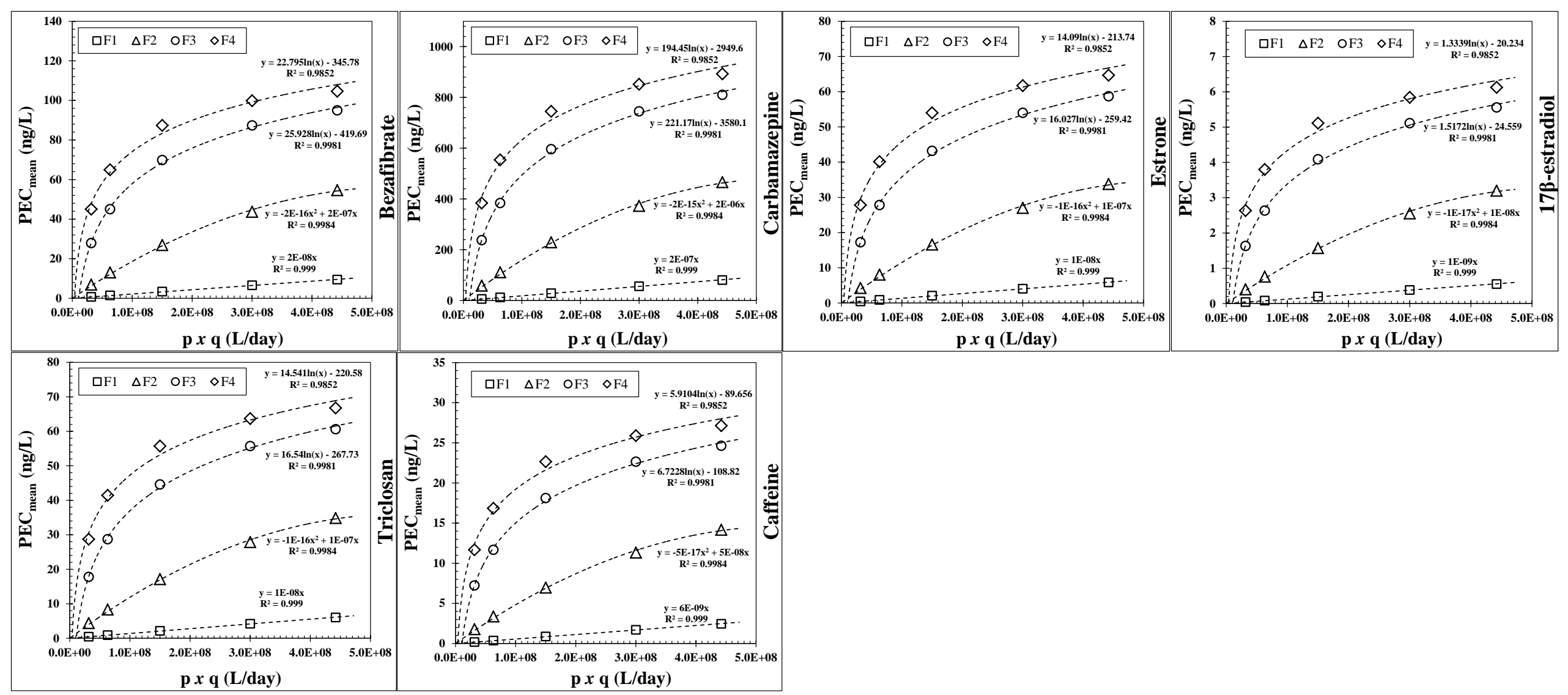

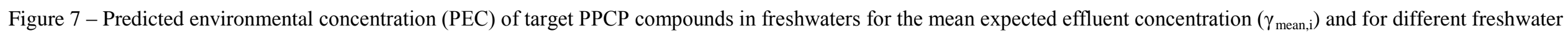
flows: F1 = 5bn L/day; F2 = 500 M L/day; F3 = 100 M L/day; F4 = 50 ML/day. 


\subsection{Estimation of freshwater concentrations of PPCPs}

The expected mean concentrations in freshwater bodies ( $\left.\mathrm{PEC}_{\text {mean,i }}\right)$, estimated according to eqn. (7) and based on the mean concentrations $\gamma_{\text {mean, } i}$ of PPCPs in WWTP effluents, are given in Figure 7. The figure shows the $\mathrm{PEC}_{\text {mean,i }}$ values for different freshwater flows, ranging from $50 \mathrm{ML} / \mathrm{day}$ to 5 bn L/day and for effluent flows from WWTP varying from 31.5-442 ML/day. The latter corresponds to a WWTP serving 1 million inhabitants. For example, if a WWTP discharges 442 $\mathrm{ML} /$ day to a freshwater body with a $50 \mathrm{ML}$ /day average flow, the mean expected concentration of acetaminophen is around $580 \mathrm{ng} / \mathrm{L}$. If a WWTP discharges $150 \mathrm{ML} /$ day to a body with a flow of $500 \mathrm{ML} /$ day, the mean PEC of acetaminophen is expected to be around $150 \mathrm{ng} / \mathrm{L}$. The best-fit curves given in Figure 7 can be used to estimate the values of PEC $_{\text {mean,i }}$ for each target PPCP over the flow ranges considered here. It can be noted from the figure that the best-fit relationship between the PEC and the volume of WWTP effluent changes with the freshwater flow: it is logarithmic for the lower flow range (50-100 ML/day), polynomial for the mid-range (500 ML/day) and linear for the highest flow (5 bn L/day).

\section{Conclusions}

This paper has proposed a new methodology for estimating expected concentrations of PPCPs in influents, effluents and sludge of conventional WWTPs, as well as their expected concentrations in freshwaters. Application of the methodology has been illustrated for 14 PPCPs for which the data were available; however, the methodology is generic and can be applied to other PPCPs or further emerging pollutants if and when the data become available. One of the advantages of this methodology is that enables more accurate and yet relatively simple estimates of the concentrations of PPCPs, reducing the need for direct measurements. Another advantage is that the database can be continuously updated, adding other compounds and types of WWTP.

The methodology could also assist in environmental risk assessments (ERA) by linking consumption of PPCPs with environmental concentrations, taking into account the actual measured data rather than relying solely on production or consumption data for PPCPs. Moreover, the outputs could be used for development of policy and regulations. For example, regulation could impose limits on the concentrations of these compounds in WWTPs effluents, also determining the necessity for monitoring the effluents for the presence of PPCP compounds. This is important not only because of the environmental pollution but also due to the increasing pressure on traditional water resources associated with pollution, urbanisation and climate change, which is necessitating reuse of wastewater in many regions worldwide. As a result, legislation to limit the presence of PPCP compounds in wastewaters intended for reuse as potable water has been considered in some regions. For example, California has recently introduced regulations for monitoring of some PPCPs in wastewaters intended for reuse (EPA 2012, NRC 2012).

Depending on the intended wastewater reuse, the adoption of advanced treatment techniques in WWTPs may be necessary in future to aid the removal of PPCPs. Thus, the methodology proposed in this work could also be applied to estimate the concentrations that such plants should expect in their influents from conventional treatment and the removal efficiencies that they should achieve to render the reused water safe for human health and aquatic organisms. This in turn could aid the selection and design of most effective advanced treatment plants to enable wastewater reuse.

Furthermore, environmental legislation for the traditional sewage sludge handling routes, such as agricultural spreading, is becoming increasingly more stringent, with some PPCP compounds already monitored in some European countries (Ellis 2006, Moran \& Dann 2008, Roig 2010). Therefore, the results of this research could also be helpful for these purposes, helping to determine the expected concentrations in the sludge and to set the appropriate legislative limits. 


\section{Nomenclature}

A dataset of $I M_{\text {inf } f, i}$ values (mg/inhab year)

B dataset of $R_{\text {efficiency,s }}$ values (\%)

$\mathrm{C}_{\text {eff,i }} \quad$ concentration of PPCP compound $i$ in the effluent of a WWTP $(\mu \mathrm{g} / \mathrm{L})$

$\mathrm{C}_{\mathrm{inf}, \mathrm{i}} \quad$ concentration of PPCP compound $i$ in the WWTP influent $(\mu \mathrm{g} / \mathrm{L})$

$\mathrm{F} \quad$ daily flow of a freshwater body (L/day)

$\mathrm{IM}_{\mathrm{inf,i}} \quad$ annual per-capita influx of PPCP compound $i$ into WWTP (mg/inhab year)

$\mathrm{K}_{\mathrm{d}, \mathrm{i}} \quad$ solid-water distribution coefficient of compound $i(\mathrm{~L} / \mathrm{kg})$

$\mathrm{p} \quad$ population served by WWTP (number of inhabitants)

$\mathrm{PEC}_{\mathrm{range}, \mathrm{i}} \quad$ predicted environmental concentration range of compound $i$ in freshwater after the release of WWTP effluent $(\mu \mathrm{g} / \mathrm{L})$

q average per-capita daily wastewater influent into WWTP (L/inhabday)

Q daily wastewater influent into WWTP (L/day)

$\mathrm{R}_{\text {efficiency,i }} \quad$ removal efficiency of PPCP compound $i$ in a WWTP (\%)

$\mathrm{S}_{\mathrm{DM}} \quad$ per-capita amount of dry matter in the sludge $(\mathrm{kg} / \mathrm{inhab}$ day)

$\mathrm{S}_{\text {range, } \mathrm{i}} \quad$ concentration range of compound $i$ in the sludge $(\mathrm{kg} / \mathrm{kg})$

Greek symbols:

$\alpha_{\text {range,i }} \quad$ estimated daily influx range for compound $i$ in WWTP (g/day)

$\beta_{\text {range,i }} \quad$ estimated influent concentration range for PPCP compound $i(\mu \mathrm{g} / \mathrm{L})$

$\gamma_{\text {range,i }} \quad$ estimated effluent concentration range for PPCP compound $i(\mu \mathrm{g} / \mathrm{L})$

$\lambda_{\text {range, } \mathrm{i}} \quad I M_{\text {inf }, i}$ value for compound $i$ within the interquartile range (mg/inhab year)

\section{Acknowledgements}

The authors would like to acknowledge CAPES/CNPq for the financial support.

\section{Appendix A. Supplementary data}

The Supplementary information includes data on datasets A and B, physicochemical properties, removal efficiency of the target PPCPs in WWTPs and concentrations of PPCPs in the sludge.

\section{References}

Atkinson SK, Marlatt VL, Kimpe LE, Lean DRS, Trudeau VL, Blais JM. 2012. The occurrence of steroidal estrogens in south-eastern Ontario wastewater treatment plants. Sci. Total Environ. 430:119-25

Baronti C, Curini R, D\&apos;Ascenzo G, Di Corcia A, Gentili A, Samperi R. 2000. Monitoring natural and synthetic estrogens at activated sludge sewage treatment plants and in a receiving river water. Environ. Sci. Technol. 34(24):5059-66

Batt AL, Kim S, Aga DS. 2007. Comparison of the occurrence of antibiotics in four full-scale wastewater treatment plants with varying designs and operations. Chemosphere. 68(3):428-35

Behera SK, Kim HW, Oh JE, Park HS. 2011. Occurrence and removal of antibiotics, hormones and several other pharmaceuticals in wastewater treatment plants of the largest industrial city of Korea. Sci. Total Environ. 409(20):4351-60

Benotti MJ, Trenholm R a, Vanderford BJ, Holady JC, Stanford BD, Snyder S a. 2009. Pharmaceuticals and endocrine disrupting compounds in U.S. drinking water. Environ. Sci. Technol. 43(3):597-603

Blair B, Nikolaus A, Hedman C, Klaper R, Grundl T. 2015. Evaluating the degradation, sorption, and negative mass balances of pharmaceuticals and personal care products during wastewater treatment. Chemosphere. 134:395-401

Bolong N, Ismail a. F, Salim MR, Matsuura T. 2009. A review of the effects of emerging contaminants in wastewater and options for their removal. Desalination. 238(1-3):229-46

Boxall ABA, Keller VDJ, Straub JO, Monteiro SC, Fussell R, Williams RJ. 2014. Exploiting monitoring data in environmental exposure modelling and risk assessment of pharmaceuticals. 
Environ. Int. 73:176-85

Carballa M, Fink G, Omil F, Lema JM, Ternes T. 2008. Determination of the solid-water distribution coefficient $(\mathrm{Kd})$ for pharmaceuticals, estrogens and musk fragrances in digested sludge. Water Res. 42(1-2):287-95

Carballa M, Omil F, Lema JM, Llompart M, García-Jares C, et al. 2004. Behavior of pharmaceuticals, cosmetics and hormones in a sewage treatment plant. Water Res. 38(12):2918-26

Carmona E, Andreu V, Picó Y. 2014. Occurrence of acidic pharmaceuticals and personal care products in Turia River Basin: From waste to drinking water. Sci. Total Environ. 484(1):53-63

Celle-Jeanton H, Schemberg D, Mohammed N, Huneau F, Bertrand G, et al. 2014. Evaluation of pharmaceuticals in surface water: Reliability of PECs compared to MECs. Environ. Int. 73:10 21

Choi K, Kim Y, Park J, Park CK, Kim M, et al. 2008. Seasonal variations of several pharmaceutical residues in surface water and sewage treatment plants of Han River, Korea. Sci. Total Environ. 405(1-3):120-28

Christensen AM, Markussen B, Baun A, Halling-Sørensen B. 2009. Probabilistic environmental risk characterization of pharmaceuticals in sewage treatment plant discharges. Chemosphere. 77(3):351-58

Clara M, Kreuzinger N, Strenn B, Gans O, Kroiss H. 2005. The solids retention time - A suitable design parameter to evaluate the capacity of wastewater treatment plants to remove micropollutants. Water Res. 39(1):97-106

Clara M, Strenn B, Kreuzinger N. 2004. Carbamazepine as a possible anthropogenic marker in the aquatic environment: Investigations on the behaviour of Carbamazepine in wastewater treatment and during groundwater infiltration. Water Res. 38(4):947-54

Cleuvers M. 2003. Aquatic ecotoxicity of pharmaceuticals including the assessment of combination effects. Toxicol. Lett. 142(3):185-94

Conkle JL, White JR, Metcalfe CD. 2008. Reduction of pharmaceutically active compounds by a lagoon wetland wastewater treatment system in Southeast Louisiana. Chemosphere. 73(11):1741-48

Daughton CG, Ternes TA. 1999. Pharmaceuticals and personal care products in the environment: Agents of subtle change? Environ. Health Perspect. 107:907-38

Ellis JB. 2006. Pharmaceutical and personal care products (PPCPs) in urban receiving waters. Environ. Pollut. 144(1):184-89

Environmental Agency. 2008. International comparisons of domestic per capita consumption. Bristol, UK

EPA. 2012. Guidelines for Water Reuse

Esperanza M, Suidan MT, Marfil-Vega R, Gonzalez C, Sorial G a., et al. 2007. Fate of sex hormones in two pilot-scale municipal wastewater treatment plants: Conventional treatment. Chemosphere. 66(8):1535-44

European Commission. 2015. Commission implementing decision 2015/495. Dir. 2008/105/EC

Evgenidou EN, Konstantinou IK, Lambropoulou DA. 2014. Occurrence and removal of transformation products of PPCPs and illicit drugs in wastewaters: A review. Sci. Total Environ. 505:905-26

Farré M La, Pérez S, Kantiani L, Barceló D. 2008. Fate and toxicity of emerging pollutants, their metabolites and transformation products in the aquatic environment. TrAC - Trends Anal. Chem. 27(11):991-1007

Fent K, Weston A a., Caminada D. 2006. Ecotoxicology of human pharmaceuticals. Aquat. Toxicol. 76(2):122-59

Gao P, Ding Y, Li H, Xagoraraki I. 2012. Occurrence of pharmaceuticals in a municipal wastewater treatment plant: Mass balance and removal processes. Chemosphere. 88(1):17-24

Gottschall N, Topp E, Metcalfe C, Edwards M, Payne M, et al. 2012. Pharmaceutical and personal care products in groundwater, subsurface drainage, soil, and wheat grain, following a high 
single application of municipal biosolids to a field. Chemosphere. 87(2):194-203

Gracia-Lor E, Sancho J V., Serrano R, Hernández F. 2012. Occurrence and removal of pharmaceuticals in wastewater treatment plants at the Spanish Mediterranean area of Valencia. Chemosphere. 87(5):453-62

Gulkowska a., Leung HW, So MK, Taniyasu S, Yamashita N, et al. 2008. Removal of antibiotics from wastewater by sewage treatment facilities in Hong Kong and Shenzhen, China. Water Res. 42(1-2):395-403

Hashimoto T, Onda K, Nakamura Y, Tada K, Miya a., Murakami T. 2007. Comparison of natural estrogen removal efficiency in the conventional activated sludge process and the oxidation ditch process. Water Res. 41(10):2117-26

Hill R, Chu M. 2009. The Pharmerging Future. Pharm. Exec. 29(7):44-52

Jelic A, Gros M, Ginebreda A, Cespedes-Sánchez R, Ventura F, et al. 2011. Occurrence, partition and removal of pharmaceuticals in sewage water and sludge during wastewater treatment. Water Res. 45(3):1165-76

Jones $\mathrm{O}$ a H, Voulvoulis N, Lester JN. 2007. The occurrence and removal of selected pharmaceutical compounds in a sewage treatment works utilising activated sludge treatment. Environ. Pollut. 145(3):738-44

Kagle J, Porter AW, Murdoch RW, Rivera-Cancel G, Hay AG. 2009. Chapter 3 Biodegradation of Pharmaceutical and Personal Care Products, Vol. 67. Elsevier Inc. 1st ed.

Karnjanapiboonwong A, Suski JG, Shah A a., Cai Q, Morse AN, Anderson T a. 2011. Occurrence of PPCPs at a Wastewater Treatment Plant and in Soil and Groundwater at a Land Application Site. Water, Air, Soil Pollut. 216(1-4):257-73

Kasprzyk-Hordern B, Dinsdale RM, Guwy AJ. 2009. The removal of pharmaceuticals, personal care products, endocrine disruptors and illicit drugs during wastewater treatment and its impact on the quality of receiving waters. Water Res. 43(2):363-80

Katsoyiannis A, Samara C. 2005. Persistent organic pollutants (POPs) in the conventional activated sludge treatment process: Fate and mass balance. Environ. Res. 97(3):245-57

Koh YKK, Chiu TY, Boobis A, Cartmell E, Scrimshaw MD, Lester JN. 2008. Treatment and removal strategies for estrogens from wastewater. Environ. Technol. 29(3):245-67

Kumar A, Xagoraraki I. 2010. Human health risk assessment of pharmaceuticals in water: An uncertainty analysis for meprobamate, carbamazepine, and phenytoin. Regul. Toxicol. Pharmacol. 57(2-3):146-56

Leung HW, Minh TB, Murphy MB, Lam JCW, So MK, et al. 2012. Distribution, fate and risk assessment of antibiotics in sewage treatment plants in Hong Kong, South China. Environ. Int. 42(1):1-9

Li B, Zhang T. 2011. Mass flows and removal of antibiotics in two municipal wastewater treatment plants. Chemosphere. 83(9):1284-89

Lindberg RH, Wennberg P, Johansson MI, Tysklind M, Andersson B a V. 2005. Screening of human antibiotic substances and determination of weekly mass flows in five sewage treatment plants in Sweden. Environ. Sci. Technol. 39(10):3421-29

Lindqvist N, Tuhkanen T, Kronberg L. 2005. Occurrence of acidic pharmaceuticals in raw and treated sewages and in receiving waters. Water Res. 39(11):2219-28

Lishman L, Smyth SA, Sarafin K, Kleywegt S, Toito J, et al. 2006. Occurrence and reductions of pharmaceuticals and personal care products and estrogens by municipal wastewater treatment plants in Ontario, Canada. Sci. Total Environ. 367(2-3):544-58

Liu J-L, Wong M-H. 2013. Pharmaceuticals and personal care products (PPCPs): A review on environmental contamination in China. Environ. Int. 59(0):208-24

Loffler D, Rombke J, Meller M, Ternes T a. 2005. Environmental fate of pharmaceuticals in water/ sediment systems. Environ. Sci. Technol. 39(14):5209-18

Luo Y, Guo W, Ngo HH, Nghiem LD, Hai FI, et al. 2014. A review on the occurrence of micropollutants in the aquatic environment and their fate and removal during wastewater treatment. Sci. Total Environ. 473-474:619-41 
Martín J, Camacho-Muñoz D, Santos JL, Aparicio I, Alonso E. 2012. Occurrence of pharmaceutical compounds in wastewater and sludge from wastewater treatment plants: Removal and ecotoxicological impact of wastewater discharges and sludge disposal. J. Hazard. Mater. 239240:40-47

Maurer M, Escher BI, Richle P, Schaffner C, Alder a. C. 2007. Elimination of Beta-blockers in sewage treatment plants. Water Res. 41(7):1614-22

McClellan K, Halden RU. 2010. Pharmaceuticals and personal care products in archived U.S. biosolids from the 2001 EPA national sewage sludge survey. Water Res. 44(2):658-68

Metcalfe CD, Koenig BG, Bennie DT, Servos M, Ternes T a, Hirsch R. 2003. Occurrence of neutral and acidic drugs in the effluents of Canadian sewage treatment plants. Environ. Toxicol. Chem. 22(12):2872-80

Michael I, Rizzo L, McArdell CS, Manaia CM, Merlin C, et al. 2013. Urban wastewater treatment plants as hotspots for the release of antibiotics in the environment: A review. Water Res. 47(3):957-95

Miège C, Choubert JM, Ribeiro L, Eusèbe M, Coquery M. 2009. Fate of pharmaceuticals and personal care products in wastewater treatment plants - Conception of a database and first results. Environ. Pollut. 157(5):1721-26

Moran D, Dann S. 2008. The economic value of water use: Implications for implementing the Water Framework Directive in Scotland. J. Environ. Manage. 87(3):484-96

Muñoz I, José Gómez M, Molina-Díaz A, Huijbregts M a J, Fernández-Alba AR, García-Calvo E. 2008. Ranking potential impacts of priority and emerging pollutants in urban wastewater through life cycle impact assessment. Chemosphere. 74(1):37-44

Nakada N, Shinohara H, Murata A, Kiri K, Managaki S, et al. 2007. Removal of selected pharmaceuticals and personal care products (PPCPs) and endocrine-disrupting chemicals (EDCs) during sand filtration and ozonation at a municipal sewage treatment plant. Water Res. 41(19):4373-82

Nakada N, Tanishima T, Shinohara H, Kiri K, Takada H. 2006. Pharmaceutical chemicals and endocrine disrupters in municipal wastewater in Tokyo and their removal during activated sludge treatment. Water Res. 40(17):3297-3303

NRC. 2012. Water Reuse : Expanding the Nation's Water Supply Through Reuse of Municipal Wastewater. Washington DC

Onesios KM, Yu JT, Bouwer EJ. 2009. Biodegradation and removal of pharmaceuticals and personal care products in treatment systems: A review. Biodegradation. 20(4):441-66

Oosterhuis M, Sacher F, ter Laak TL. 2013. Prediction of concentration levels of metformin and other high consumption pharmaceuticals in wastewater and regional surface water based on sales data. Sci. Total Environ. 442:380-88

Petrie B, Barden R, Kasprzyk-Hordern B. 2015. A review on emerging contaminants in wastewaters and the environment: Current knowledge, understudied areas and recommendations for future monitoring. Water Res. 72:3-27

Petrovic M, de Alda MJL, Diaz-Cruz S, Postigo C, Radjenovic J, et al. 2009. Fate and removal of pharmaceuticals and illicit drugs in conventional and membrane bioreactor wastewater treatment plants and by riverbank filtration. Philos. Trans. A. Math. Phys. Eng. Sci. 367(1904):3979-4003

Potter K. 2006. Methods for Presenting Statistical Information: The Box Plot. Vis. Large Unstructured Data Sets. 4:97-106

Quintana JB, Weiss S, Reemtsma T. 2005. Pathways and metabolites of microbial degradation of selected acidic pharmaceutical and their occurrence in municipal wastewater treated by a membrane bioreactor. Water Res. 39(12):2654-64

Radjenović J, Petrović M, Barceló D. 2009. Fate and distribution of pharmaceuticals in wastewater and sewage sludge of the conventional activated sludge (CAS) and advanced membrane bioreactor (MBR) treatment. Water Res. 43(3):831-41

Ratola N, Cincinelli A, Alves A, Katsoyiannis A. 2012. Occurrence of organic microcontaminants 
Accepted for publication in Science of the Total Environment 622-623 (2018) 1417-1430

in the wastewater treatment process. A mini review. J. Hazard. Mater. 239-240:1-18

Roberts PH, Thomas K V. 2006. The occurrence of selected pharmaceuticals in wastewater effluent and surface waters of the lower Tyne catchment. Sci. Total Environ. 356(1-3):143-53

Roig B. 2010. Pharmaceuticals in the Environment - Current Knoledge and Need Assessment to Reduce Presence and Impact. London: IWA publishing

Santos JL, Aparicio I, Alonso E. 2007. Occurrence and risk assessment of pharmaceutically active compounds in wastewater treatment plants. A case study: Seville city (Spain). Environ. Int. 33(4):596-601

Schlüsener MP, Bester K. 2008. Behavior of steroid hormones and conjugates during wastewater treatment - A comparison of three sewage treatment plants. Clean - Soil, Air, Water. 36(1):2533

Shannon M a, Bohn PW, Elimelech M, Georgiadis JG, Mariñas BJ, Mayes AM. 2008. Science and technology for water purification in the coming decades. Nature. 452(7185):301-10

Siemens J, Huschek G, Siebe C, Kaupenjohann M. 2008. Concentrations and mobility of human pharmaceuticals in the world's largest wastewater irrigation system, Mexico City-Mezquital Valley. Water Res. 42(8-9):2124-34

Sim WJ, Lee JW, Oh JE. 2010. Occurrence and fate of pharmaceuticals in wastewater treatment plants and rivers in Korea. Environ. Pollut. 158(5):1938-47

Stasinakis AS, Kordoutis CI, Tsiouma VC, Gatidou G, Thomaidis NS. 2010. Removal of selected endocrine disrupters in activated sludge systems: Effect of sludge retention time on their sorption and biodegradation. Bioresour. Technol. 101(7):2090-95

StuerLauridsen F, Birkved M, Hansen LP, Lutzhoft HCH, HallingSorensen B. 2000. Environmental risk assessment of human pharmaceuticals in Denmark after normal therapeutic use (Vol 40, pg 783, 2000). Chemosphere. 41(9):1509

Sui Q, Huang J, Deng S, Yu G, Fan Q. 2010. Occurrence and removal of pharmaceuticals, caffeine and DEET in wastewater treatment plants of Beijing, China. Water Res. 44(2):417-26

Tauxe-Wuersch A, De Alencastro LF, Grandjean D, Tarradellas J. 2005. Occurrence of several acidic drugs in sewage treatment plants in Switzerland and risk assessment. Water Res. 39(9):1761-72

Thomas PM, Foster GD. 2005. Tracking acidic pharmaceuticals, caffeine, and triclosan through the wastewater treatment process. Environ. Toxicol. Chem. 24(1):25-30

Verlicchi P, Al Aukidy M, Jelic A, Petrović M, Barceló D. 2014. Comparison of measured and predicted concentrations of selected pharmaceuticals in wastewater and surface water: A case study of a catchment area in the Po Valley (Italy). Sci. Total Environ. 470-471:844-54

Verlicchi P, Al Aukidy M, Zambello E. 2012. Occurrence of pharmaceutical compounds in urban wastewater: Removal, mass load and environmental risk after a secondary treatment-A review. Sci. Total Environ. 429:123-55

Verlicchi P, Zambello E. 2015. Pharmaceuticals and personal care products in untreated and treated sewage sludge: Occurrence and environmental risk in the case of application on soil - A critical review. Sci. Total Environ. 538:750-67

Walters E, McClellan K, Halden RU. 2010. Occurrence and loss over three years of 72 pharmaceuticals and personal care products from biosolids-soil mixtures in outdoor mesocosms. Water Res. 44(20):6011-20

Wang L, Ying GG, Zhao JL, Yang XB, Chen F, et al. 2010. Occurrence and risk assessment of acidic pharmaceuticals in the Yellow River, Hai River and Liao River of north China. Sci. Total Environ. 408(16):3139-47

Watkinson a. J, Murby EJ, Costanzo SD. 2007. Removal of antibiotics in conventional and advanced wastewater treatment: Implications for environmental discharge and wastewater recycling. Water Res. 41(18):4164-76

WHO. 2004. The World Medicines Situation. Geneva, CH

Xu J, Wu L, Chang AC. 2009. Degradation and adsorption of selected pharmaceuticals and personal care products (PPCPs) in agricultural soils. Chemosphere. 77(10):1299-1305 
Accepted for publication in Science of the Total Environment 622-623 (2018) 1417-1430

Xu N, Xu YF, Xu S, Li J, Tao HC. 2012. Removal of estrogens in municipal wastewater treatment plants: A Chinese perspective. Environ. Pollut. 165:215-24

Xu W, Zhang G, Li X, Zou S, Li P, et al. 2007. Occurrence and elimination of antibiotics at four sewage treatment plants in the Pearl River Delta (PRD), South China. Water Res. 41(19):4526-34

Yang X, Flowers RC, Weinberg HS, Singer PC. 2011. Occurrence and removal of pharmaceuticals and personal care products (PPCPs) in an advanced wastewater reclamation plant. Water Res. 45(16):5218-28

Yazdankhah SP, Scheie A a, Høiby EA, Lunestad B-T, Heir E, et al. 2006. Triclosan and antimicrobial resistance in bacteria: an overview. Microb. Drug Resist. 12(2):83-90

Ying G-G, Kookana RS, Kolpin DW. 2009. Occurrence and removal of pharmaceutically active compounds in sewage treatment plants with different technologies. J. Environ. Monit. 11(8):1498-1505

Zhang Y, Geißen SU. 2010. Prediction of carbamazepine in sewage treatment plant effluents and its implications for control strategies of pharmaceutical aquatic contamination. Chemosphere. 80(11):1345-52

Zhou JL, Zhang ZL, Banks E, Grover D, Jiang JQ. 2009. Pharmaceutical residues in wastewater treatment works effluents and their impact on receiving river water. J. Hazard. Mater. 166(23):655-61

Zhou Y, Zha J, Wang Z. 2012. Occurrence and fate of steroid estrogens in the largest wastewater treatment plant in Beijing, China. Environ. Monit. Assess. 184(11):6799-6813

Zorita S, Mårtensson L, Mathiasson L. 2009. Occurrence and removal of pharmaceuticals in a municipal sewage treatment system in the south of Sweden. Sci. Total Environ. 407(8):276070 
A methodology for estimating concentrations of compounds from pharmaceuticals and personal care products in wastewater treatment plants and in freshwaters

Raphael Ricardo Zepon Tarpani and Adisa Azapagic

\section{Supplementary information}

\section{List of contents}

S1. Datasets A and B

S2. Physicochemical properties and removal efficiency of target PPCPs in WWTPs

S3. Concentrations of PPCPs in the sludge 
Accepted for publication in Science of the Total Environment 622-623 (2018) 1417-1430

\section{S1. Datasets A and B}

Table S1. Estimated annual per-capita influx into WWTPs of target PPCPs (dataset A)

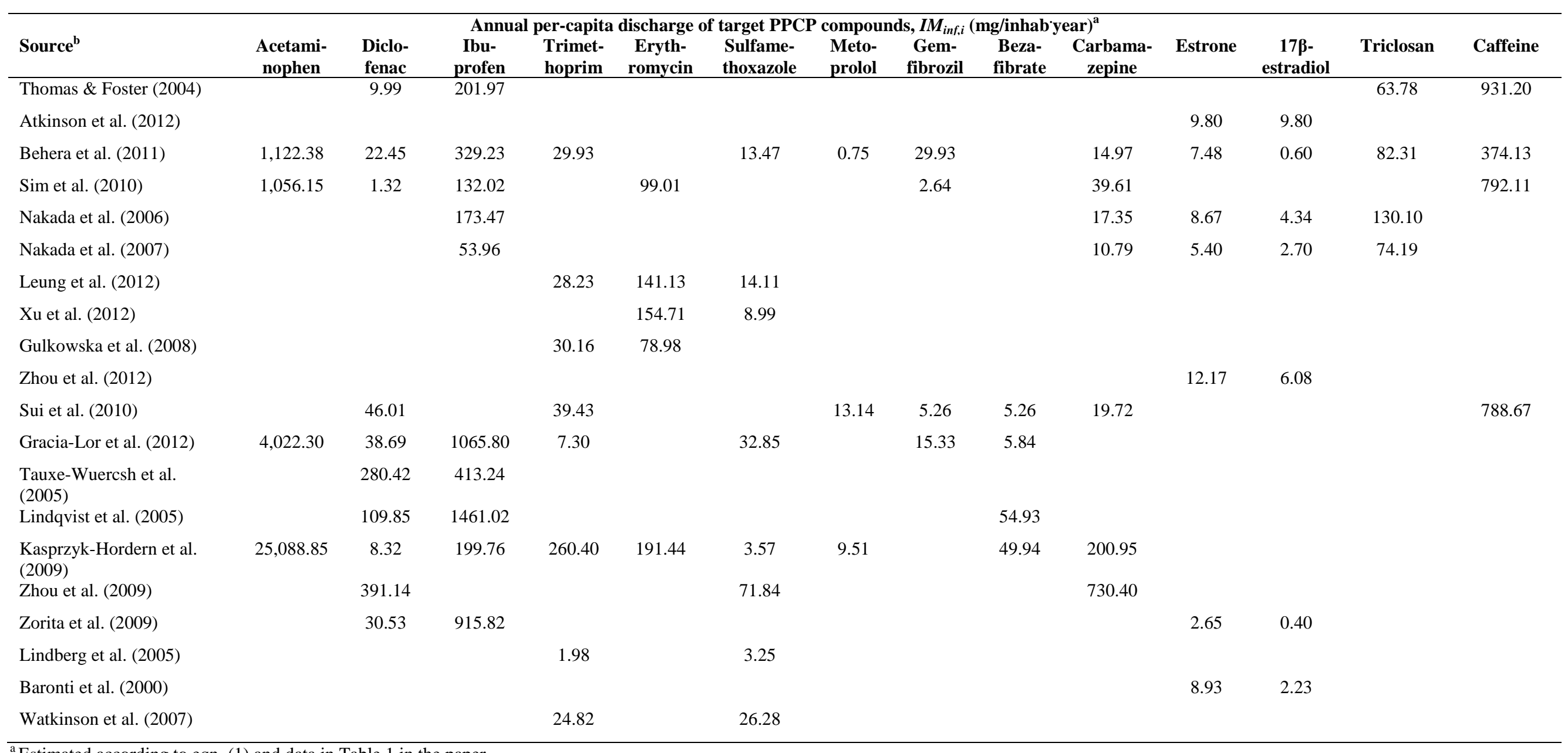

${ }^{\text {a }}$ Estimated according to eqn. (1) and data in Table 1 in the paper.

${ }^{\mathrm{b}}$ For the list of references, see the paper. 
Accepted for publication in Science of the Total Environment 622-623 (2018) 1417-1430

Table S2. Estimated removal efficiencies for the target PPCP compounds (dataset B) ${ }^{\mathrm{a}}$.

\begin{tabular}{|c|c|c|c|c|c|c|c|c|c|c|c|c|c|c|}
\hline \multirow[b]{2}{*}{ Source $^{b}$} & \multirow[b]{2}{*}{$\begin{array}{c}\text { Acetami- } \\
\text { nophen }\end{array}$} & \multirow[b]{2}{*}{$\begin{array}{l}\text { Diclo- } \\
\text { fenac }\end{array}$} & \multirow[b]{2}{*}{$\begin{array}{c}\text { Ibu- } \\
\text { profen }\end{array}$} & \multirow[b]{2}{*}{$\begin{array}{l}\text { Trime- } \\
\text { thoprim }\end{array}$} & \multirow[b]{2}{*}{$\begin{array}{c}\text { Eryth- } \\
\text { romycin }\end{array}$} & \multicolumn{3}{|c|}{ Removal rate, $\mathbf{R}_{\text {rate, }}(\%)$} & \multirow[b]{2}{*}{$\begin{array}{l}\text { Beza- } \\
\text { fibrate }\end{array}$} & \multirow[b]{2}{*}{$\begin{array}{l}\text { Carbama- } \\
\text { zepine }\end{array}$} & \multirow[b]{2}{*}{ Estrone } & \multirow[b]{2}{*}{$\begin{array}{c}17 \beta- \\
\text { estradiol }\end{array}$} & \multirow[b]{2}{*}{ Triclosan } & \multirow[b]{2}{*}{ Caffeine } \\
\hline & & & & & & $\begin{array}{l}\text { Sulfame- } \\
\text { thoxazole }\end{array}$ & $\begin{array}{l}\text { Meto- } \\
\text { prolol }\end{array}$ & $\begin{array}{c}\text { Gemfi- } \\
\text { brozil }\end{array}$ & & & & & & \\
\hline Gao et al. (2012) & & & & & & 90.91 & & & & -100.00 & & & & 98.33 \\
\hline Conkle et al. (2008) & 99.95 & & 99.19 & & & 92.42 & 90.48 & -10.30 & & -50.00 & & & & 99.88 \\
\hline Thomas \& Foster (2004) & & 99.98 & 99.79 & & & & & & & & & & 97.33 & 99.91 \\
\hline Batt et al. (2007) & & & & 96.71 & & 77.50 & & & & & & & & \\
\hline Yang et al. (2011) & 99.94 & 95.45 & 99.45 & 54.10 & 20.59 & 83.85 & & & & -8.70 & & & 95.74 & 99.91 \\
\hline Lishman (2006) & & 5.00 & 95.50 & & & & & 44.44 & & & 66.67 & & 100.00 & \\
\hline Atkinson et al. (2012) & & & & & & & & & & & -100.00 & 94.00 & & \\
\hline Behera et al. (2011) & 99.87 & 86.67 & 93.18 & 80.00 & & 0.00 & 20.00 & 90.00 & & 20.00 & 60.00 & 99.75 & 81.82 & 99.20 \\
\hline Sim et al. (2010) & 100.00 & 0.00 & 99.99 & & 80.00 & & & 99.50 & & 33.33 & & & & 99.67 \\
\hline Choi et al. (2008) & 99.97 & & & 77.27 & & 69.23 & & & & 60.87 & & & & 98.83 \\
\hline Nakada et al. (2006) & & & 98.75 & & & & & & & 37.50 & -25.00 & 50.00 & 83.33 & \\
\hline Nakada et al. (2007) & & & 97.50 & & & & & & & 62.50 & 50.00 & 90.00 & 78.18 & \\
\hline Hashimoto (2007) & & & & & & & & & & & -33.33 & 83.33 & & \\
\hline Leung et al. (2012) & & & & 5.00 & 0.00 & 30.00 & & & & & & & & \\
\hline Xu et al. (2012) & & & & & 13.95 & 40.00 & & & & & & & & \\
\hline Gulkowska et al. (2008) & & & & -9.52 & 7.27 & & & & & & & & & \\
\hline Zhou et al. (2012) & & & & & & & & & & & 85.00 & 95.00 & & \\
\hline Sui et al. (2010) & & 42.86 & & 66.67 & & & 10.00 & 25.00 & 75.00 & 20.00 & & & & 99.83 \\
\hline Gracia-Lor et al. (2012) & 100.00 & 35.85 & 100.00 & 10.00 & & 88.89 & & -133.33 & 25.00 & & & & & \\
\hline Carballa et al. (2004) & & & 64.05 & & & 56.90 & & & & & -100.00 & & & \\
\hline Radjenovic et al. (2009) & 98.89 & 20.45 & 98.11 & 40.00 & 34.15 & 77.78 & 25.00 & 0.00 & 79.80 & 0.00 & & & & \\
\hline Santos et al. (2006) & & & 88.42 & & & & & & & -66.67 & & & & 42.86 \\
\hline $\begin{array}{l}\text { Tauxe-Wuercsh et al. } \\
\text { (2005) }\end{array}$ & & 0.00 & 78.57 & & & & & & & & & & & \\
\hline Maurer et al. (2007) & & & & & & & 33.33 & & & & & & & \\
\hline Lindqvist et al. (2005) & & 65.00 & 91.73 & & & & & & 34.00 & & & & & \\
\hline $\begin{array}{l}\text { Kasprzyk-Hordern et al. } \\
\text { (2009) }\end{array}$ & 94.45 & -42.86 & 84.52 & 47.49 & 13.66 & 66.67 & 12.50 & & 45.24 & -47.93 & & & & \\
\hline Jones et al. (2007) & 95.00 & & 87.50 & & & & & & & & & & & \\
\hline Zhou et al. (2009) & & 91.84 & & & & 83.33 & & & & 54.10 & & & & \\
\hline Roberts \& Thomas (2006) & 99.99 & 65.31 & 44.83 & -53.85 & -81.82 & & & & & & & & & \\
\hline Zorita et al. (2009) & & -113.04 & 98.70 & & & & & & & & -250.00 & 16.67 & & \\
\hline Lindberg et al. (2005) & & & & 12.00 & & 53.66 & & & & & & & & \\
\hline Baronti et al. (2000) & & & & & & & & & & & 25.00 & 80.00 & & \\
\hline Watkinson et al. (2007) & & & & 85.29 & & 25.00 & & & & & & & & \\
\hline
\end{tabular}

${ }^{a}$ Estimated according to eqn. (2) and data in Table 1 in the paper.

${ }^{\mathrm{b}}$ For the list of references, see the paper. 
Accepted for publication in Science of the Total Environment 622-623 (2018) 1417-1430
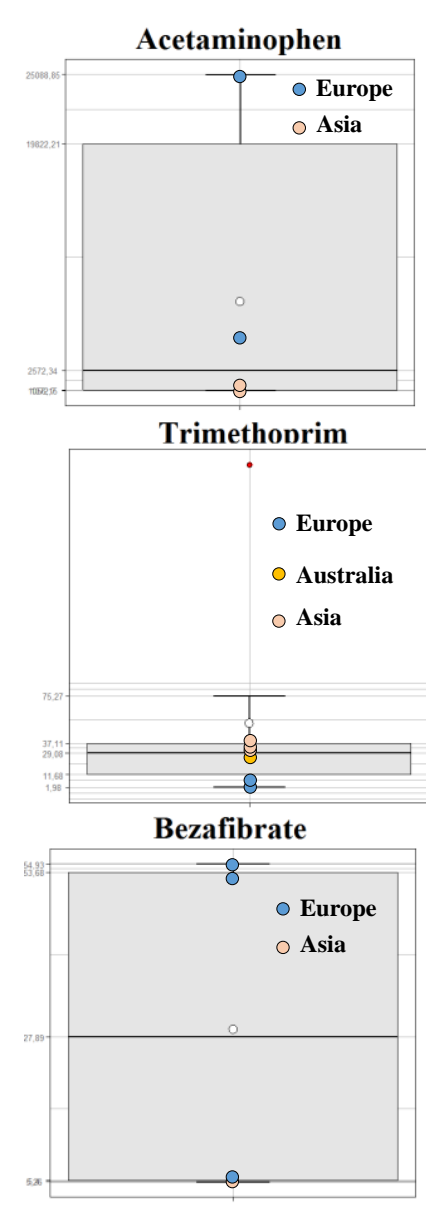
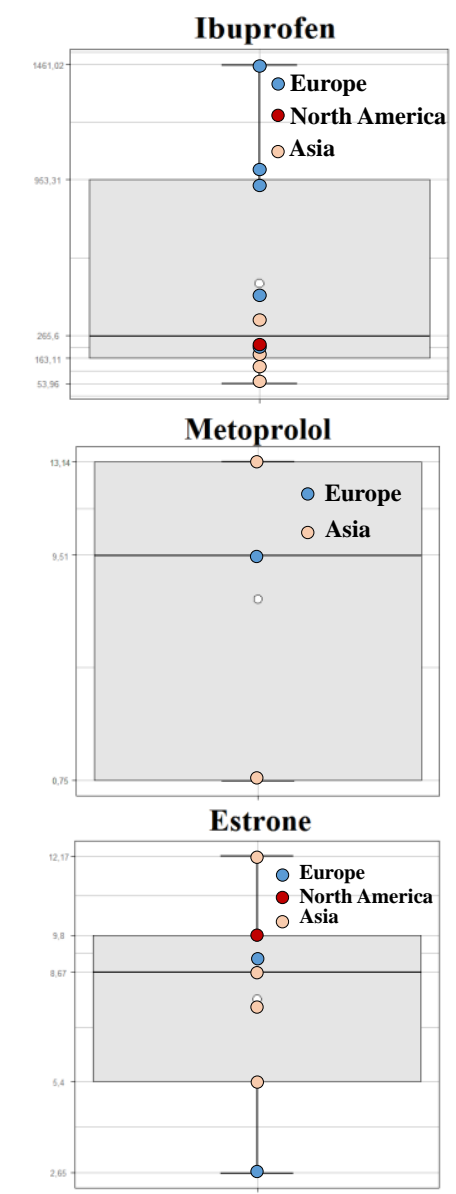

Erythromycin

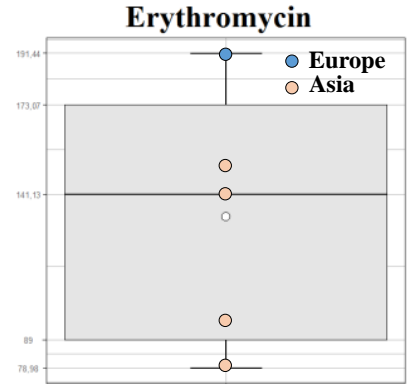

Gemfibrozil

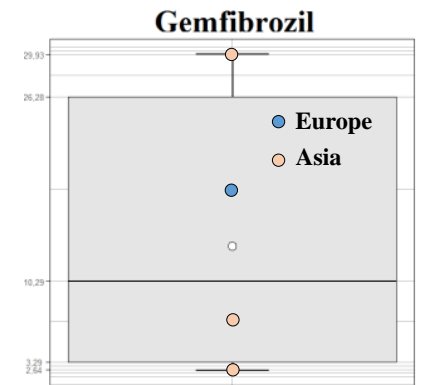

17 - Estradiol

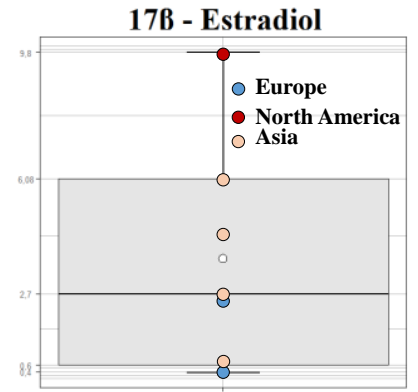

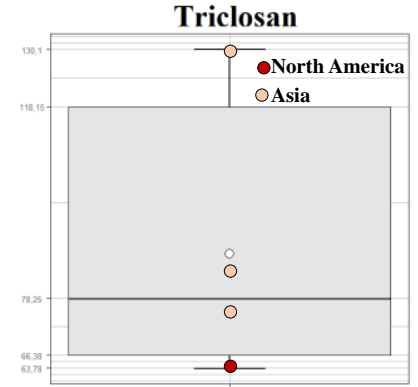

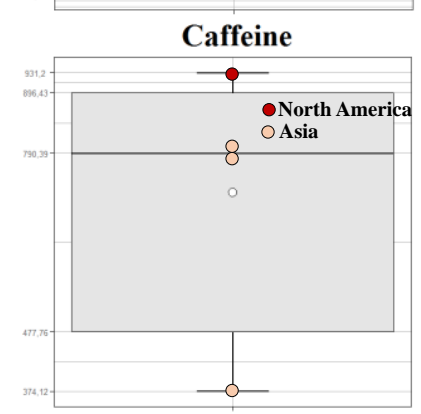

Figure S1. Box plots for the dataset A 
Accepted for publication in Science of the Total Environment 622-623 (2018) 1417-1430

Table S3. Estimated influx ranges of PPCP compounds according to a served population $p$

\begin{tabular}{|c|c|c|c|}
\hline \multirow{2}{*}{ Compound } & \multicolumn{3}{|c|}{$\alpha_{\text {range }, \mathrm{i}}(\mathrm{g} /$ day $)$} \\
\hline & $\boldsymbol{\alpha}_{\min }$ & $\boldsymbol{\alpha}_{\text {mean }}$ & $\boldsymbol{\alpha}_{\max }$ \\
\hline Acetaminophen & $2.9397 \mathrm{E}-03 \times \mathrm{p}$ & $2.8623 \mathrm{E}-02 \times \mathrm{p}$ & $5.4307 \mathrm{E}-02 \times \mathrm{p}$ \\
\hline Diclofenac & 2.7397E-05 x p & $2.2192 \mathrm{E}-04 \times \mathrm{p}$ & 4.1644E-04 x p \\
\hline Ibuprofen & $4.4658 \mathrm{E}-04 \times \mathrm{p}$ & $1.5288 \mathrm{E}-03 \times \mathrm{p}$ & $2.6110 \mathrm{E}-03 \times \mathrm{p}$ \\
\hline Trimethoprim & $3.2877 \mathrm{E}-05 \times \mathrm{p}$ & $6.7123 \mathrm{E}-05 \times \mathrm{p}$ & $1.0137 \mathrm{E}-04 \times \mathrm{p}$ \\
\hline Erythromycin & $2.4384 \mathrm{E}-04 \times \mathrm{p}$ & $3.5890 \mathrm{E}-04 \times \mathrm{p}$ & 4.7397E-04 x p \\
\hline Sulfamethoxazole & $1.3425 \mathrm{E}-05 \times \mathrm{p}$ & 4.9178E-05 x p & $8.4932 \mathrm{E}-05 \times \mathrm{p}$ \\
\hline Metoprolol & $2.0548 \mathrm{E}-06 \times \mathrm{p}$ & $1.8836 \mathrm{E}-05 \times \mathrm{p}$ & $3.5616 \mathrm{E}-05 \times \mathrm{p}$ \\
\hline Gemfibrozil & $8.2192 \mathrm{E}-06 \times \mathrm{p}$ & $3.9726 \mathrm{E}-05 \times \mathrm{p}$ & $7.1233 \mathrm{E}-05 \times \mathrm{p}$ \\
\hline Bezafibrate & $1.4247 \mathrm{E}-05 \times \mathrm{p}$ & $8.1096 \mathrm{E}-05 \times \mathrm{p}$ & $1.4795 \mathrm{E}-04 \times \mathrm{p}$ \\
\hline Carbamazepine & $4.1096 \mathrm{E}-05 \times \mathrm{p}$ & $2.9589 \mathrm{E}-04 \times \mathrm{p}$ & $5.5068 \mathrm{E}-04 \times \mathrm{p}$ \\
\hline Estrone & $1.3699 \mathrm{E}-05 \times \mathrm{p}$ & $2.0548 \mathrm{E}-05 \times \mathrm{p}$ & 2.7397E-05 x p \\
\hline $17 \beta$-Estradiol & $1.6438 \mathrm{E}-06 \times \mathrm{p}$ & $9.0411 \mathrm{E}-06 \times \mathrm{p}$ & $1.6438 \mathrm{E}-05 \times \mathrm{p}$ \\
\hline Triclosan & $1.8082 \mathrm{E}-04 \times \mathrm{p}$ & $2.5205 \mathrm{E}-04 \times \mathrm{p}$ & $3.2329 \mathrm{E}-04 \times \mathrm{p}$ \\
\hline Caffeine & $1.3096 \mathrm{E}-03 \times \mathrm{p}$ & $1.8822 \mathrm{E}-03 \times \mathrm{p}$ & $2.4548 \mathrm{E}-03 \times \mathrm{p}$ \\
\hline
\end{tabular}

Table S4. Estimated ranges for the removal of the target PPCP compounds in WWTPs

\begin{tabular}{lrrr}
\hline \multirow{2}{*}{ Compound $\boldsymbol{i}$} & \multicolumn{3}{c}{ Removal efficiency range $\boldsymbol{R}_{\text {range, } \boldsymbol{i}}(\boldsymbol{\%})$} \\
\cline { 2 - 4 } & $\mathbf{R}_{\min }$ & \multicolumn{1}{c}{$\mathbf{R}_{\operatorname{mean}}$} & $\mathbf{R}_{\max }$ \\
\hline Acetaminophen & 98.99 & 99.49 & 99.99 \\
Diclofenac & 0 & 40 & 80 \\
Ibuprofen & 88 & 93.5 & 99 \\
Trimethoprim & 10 & 42.5 & 75 \\
Erythromycin & 0 & 12.5 & 25 \\
Sulfamethoxazole & 45 & 62.5 & 80 \\
Metoprolol & 10 & 22.5 & 35 \\
Gemfibrozil & -5 & 30 & 65 \\
Bezafibrate & 35 & 55 & 75 \\
Carbamazepine & -50 & -5 & 40 \\
Estrone & -100 & -25 & 50 \\
17ß-estradiol & 65 & 80 & 95 \\
Triclosan & 82 & 89.5 & 97 \\
Caffeine & 99 & 99.45 & 99.9 \\
\hline & & &
\end{tabular}




\section{S2. Physicochemical properties and removal efficiency of target PPCPs in WWTPs}
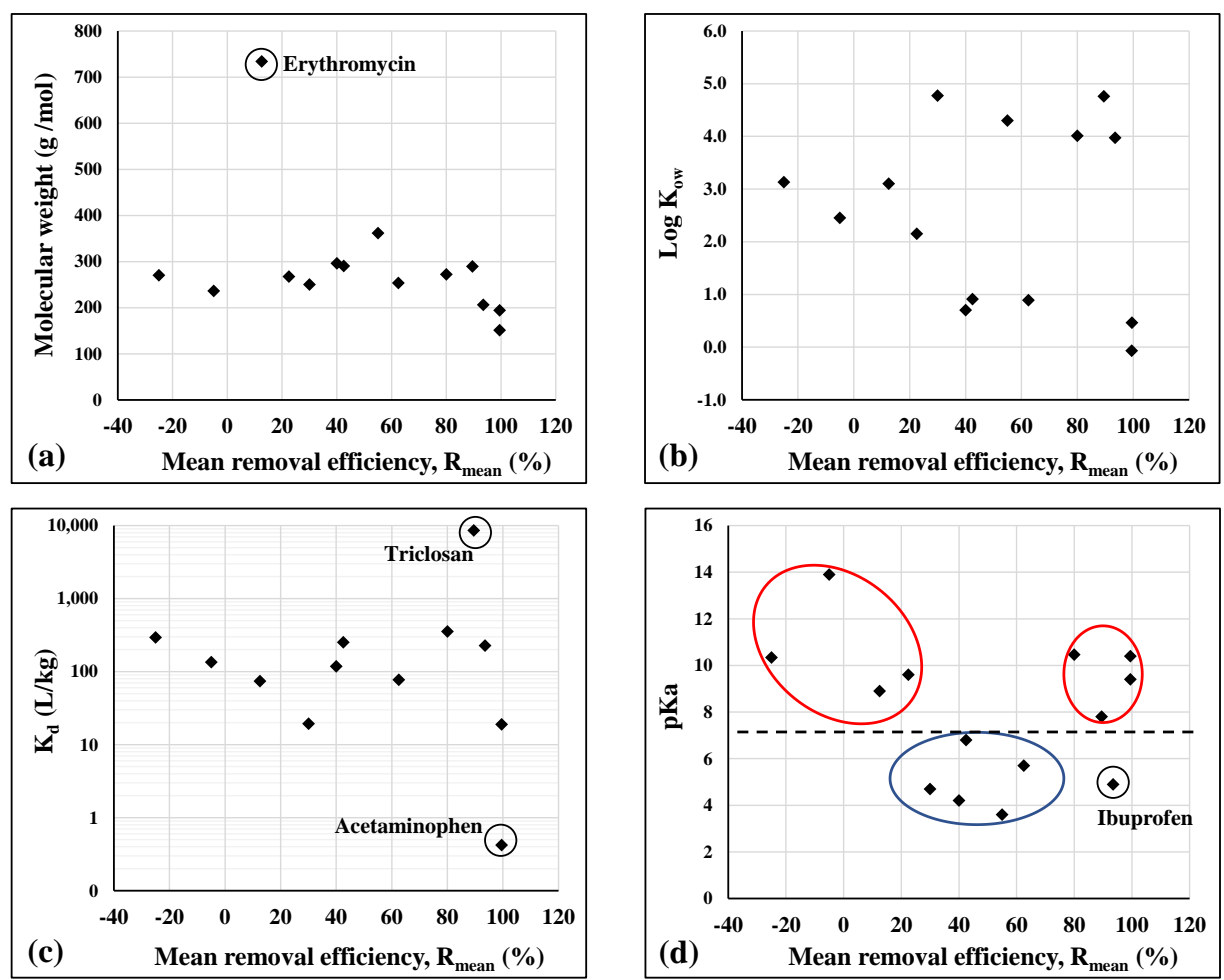

Figure S2. Mean removal efficiency of the target PPCPs in WWTPs for different molecular weights (a); octanol-water partition coefficients, Kow (b); solid-water distribution coefficient $K_{d}(\mathrm{c})$ and the acid dissociation constant, $p K_{a}(\mathrm{~d})$
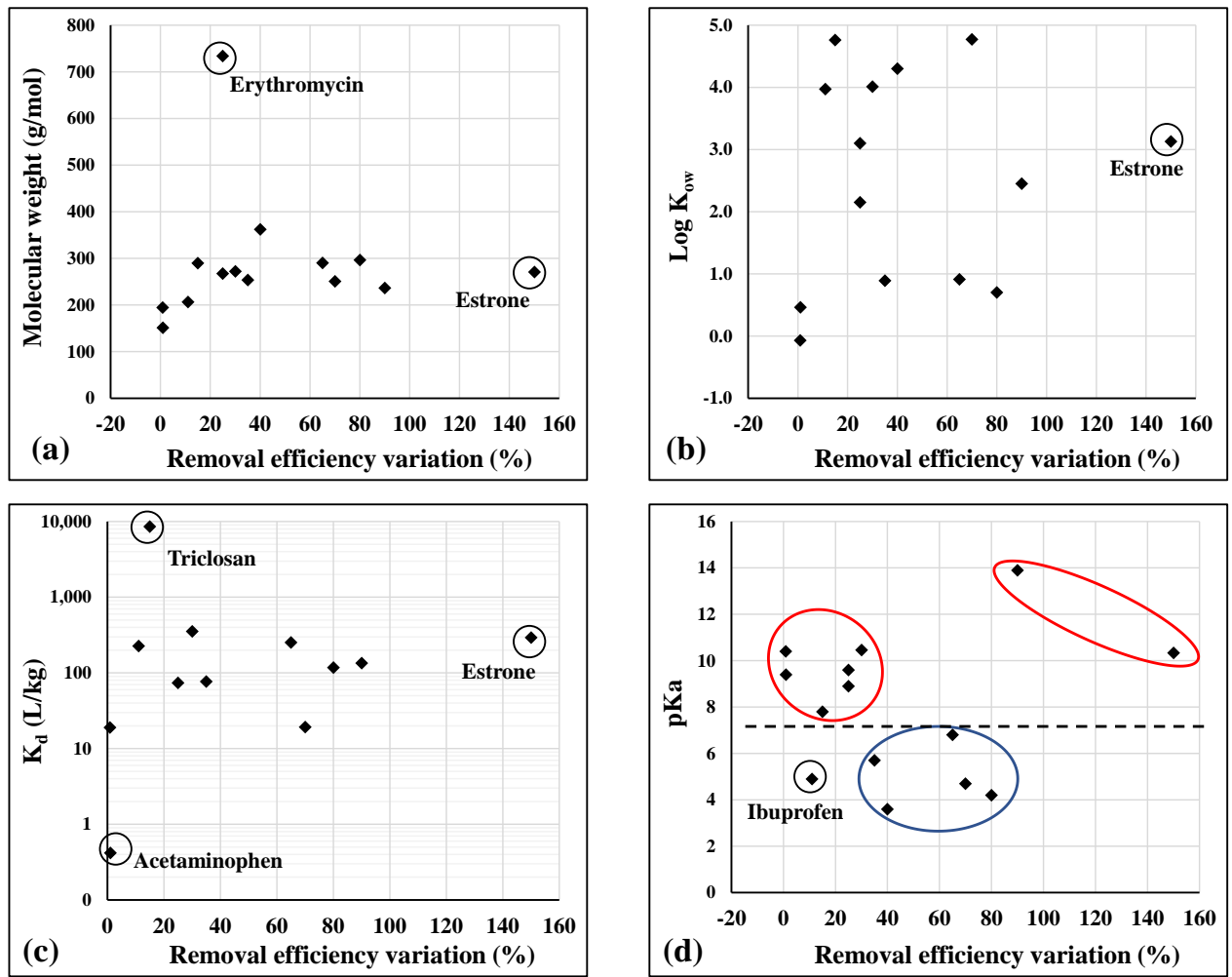

Figure S3. Variation in the removal efficiency of the target PPCPs in WWTPs for different molecular weights (a); octanol-water partition coefficients Kow (b); solid-water distribution coefficient $K_{d}$ (c) and the acidity index $p K_{a}(\mathrm{~d})$. 
Accepted for publication in Science of the Total Environment 622-623 (2018) 1417-1430

\section{S3. Concentrations of PPCPs in the sludge}

Table S5. Estimated range of concentrations of the target PPCPs in the sludge $\left(\mathrm{S}_{\text {range, }}\right)$ based on the solid-water distribution coefficient $\left(\mathrm{K}_{\mathrm{d}, \mathrm{i}}\right)$

\begin{tabular}{|c|c|c|c|c|c|}
\hline \multirow[b]{2}{*}{ Compound $i$} & \multirow{2}{*}{$\begin{array}{c}\mathbf{K}_{\mathbf{d}, \mathbf{i}} \\
(\mathrm{L} / \mathrm{kg})\end{array}$} & \multicolumn{3}{|c|}{$\mathbf{S}_{\text {range, } \mathrm{i}}(\mu \mathrm{g} / \mathrm{kg})$} & \multirow{2}{*}{$\begin{array}{c}\text { Variation } \\
\left(\mathbf{S}_{\max , \mathbf{i}}-\mathbf{S}_{\min , \mathbf{i}}\right) \\
(\mu \mathrm{g} / \mathrm{kg})\end{array}$} \\
\hline & & $\mathbf{S}_{\min , \mathbf{i}}$ & $\mathbf{S}_{\text {mean,i }}$ & $\mathbf{S}_{\max , \mathbf{i}}$ & \\
\hline Acetaminophen & 0.42 & 2.88 & 28.09 & 53.29 & 50.40 \\
\hline Diclofenac & 118.00 & 7.45 & 60.35 & 113.25 & 105.80 \\
\hline Ibuprofen & 227.51 & 231.24 & 791.62 & $1,351.98$ & $1,120.74$ \\
\hline Trimethoprim & 253.00 & 18.88 & 38.54 & 58.20 & 39.33 \\
\hline Erythromycin & 74.00 & 41.80 & 61.52 & 81.25 & 39.45 \\
\hline Sulfamethoxazole & 77.00 & 2.39 & 8.77 & 15.14 & 12.75 \\
\hline Metoprolol & - & - & - & - & - \\
\hline Gemfibrozil & 19.30 & 0.37 & 1.79 & 3.20 & 2.84 \\
\hline Bezafibrate & - & - & - & - & - \\
\hline Carbamazepine & 135.00 & 12.76 & 91.88 & 171.00 & 158.24 \\
\hline Estrone & 293.00 & 9.07 & 13.60 & 18.13 & 9.07 \\
\hline $17 \beta$-estradiol & 354.81 & 1.31 & 7.20 & 13.08 & 11.78 \\
\hline Triclosan & $8,600.00$ & $1,812.41$ & $2,526.38$ & $3,240.44$ & $1,428.02$ \\
\hline Caffeine & 19.00 & 58.01 & 83.37 & 108.73 & 50.73 \\
\hline
\end{tabular}

${ }^{\mathrm{a}}$ For $\mathrm{q}=428 \mathrm{~L} / \mathrm{inh}$ ab.day and $\mathrm{s}_{\mathrm{DM}}=50 \mathrm{~g} /$ inhab.day. 